\title{
Sub-Saharan Africa
}

\section{Forging New Trade \\ Links with Asia}

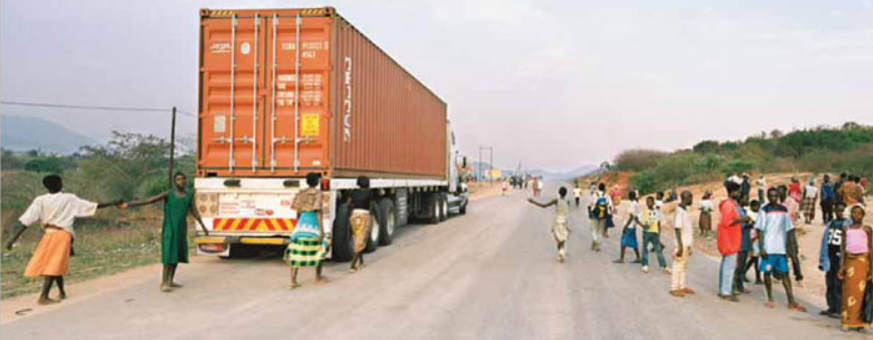

Kevin Carey, Sanjeev Gupta, Ulrich Jacoby

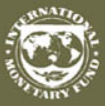

International Monetary Fund 


\section{Sub-Saharan Africa}

\section{Forging New Trade Links with Asia}

Kevin Carey, Sanjeev Gupta, and Ulrich Jacoby

International Monetary Fund Washington, DC 
Production: IMF Multimedia Services Division

Cover Design: Lai Oy Louie

Typesetting: Alicia Etchebarne-Bourdin

Cover Photo: (C) Gideon Mendel/Corbis

\section{Cataloging-in-Publication Data}

Carey, Kevin Joseph, 1967-.

Sub-Saharan Africa: forging new trade links with Asia / Kevin Carey, Sanjeev Gupta, and Ulrich Jacoby_Washington, DC: International Monetary Fund, 2007.

$$
\text { p. cm. }
$$

Includes bibliographical references.

ISBN 978-1-58906-667-0

1. Africa, Sub-Saharan-Foreign economic relations-Asia. 2. Asia-Foreign economic relations-Africa, Sub-Saharan. 3. Africa, Sub-Saharan-Commerce. 4. Africa, Sub-SaharanEconomic conditions. 5. Africa, Sub-Saharan-Economic policy. I. Gupta, Sanjeev. II. Jacoby, Ulrich. III. International Monetary Fund.

HF3874.C374 2007

Disclaimer: This publication should not be reported as representing the views or policies of the International Monetary Fund. The views expressed in this work are those of the authors and do not necessarily represent those of the IMF, its Executive Board, or its management.

Price: $\$ 27.00$

Please send orders to:

International Monetary Fund, Publication Services 700 19th Street, NW, Washington, DC 20431, U.S.A. Telephone: (202) 623-7430 Telefax: (202) 623-7201

Internet: www.imf.org 


\section{Contents}

Abbreviations $\underline{\text { v }}$

Preface vii

Chapter 1. Overview $\underline{1}$

Chapter 2. Evolution of Sub-Saharan African Trade Patterns through 2005

Trade Patterns by Destination $\quad \underline{3}$

Trade Patterns by Product $\underline{6}$

Export Patterns by Sub-Saharan African Country Grouping $\underline{10}$

Sub-Saharan Africa's Import Pattern $\quad \underline{12}$

A Closer Look at Sub-Saharan Africa's Manufacturing Exports $\quad \underline{19}$

Chapter 3. Benchmarking Sub-Saharan African Trade Performance $\quad \underline{24}$

Estimation Results

Alternative Estimation Methods

Chapter 4. Making Trade an Engine of Development $\quad \underline{34}$

Evolution of Trade Patterns and Income Growth: Experiences Outside Africa

Constraints on Manufacturing in Sub-Saharan Africa

Policy Recommendations

Appendix 1. Data Source and Notes $\quad \underline{46}$

Appendix 2. Additional Tables and Figures $\quad \underline{48}$

References $\quad \underline{51}$

Boxes

1. China's Financial Relations with Sub-Saharan Africa $\underline{4}$

2. EU-Sub-Saharan Africa Trade Arrangements $\quad \underline{39}$

3. International Service Outsourcing to Sub-Saharan Africa $\underline{42}$

Tables

1. Sectoral Composition of Exports

2. Growth Rates of Broad Export Categories

3. Destination Shares of Broad Export Categories, 1990 and 2005

iii 
4. Merchandise Exports by Geographic Grouping, Destination, and Product, 1990 and 2005

5. Merchandise Imports by Geographic Grouping, Destination, and Product, 1990 and 2005

6. Import Shares of Major Product Categories

7. Import Shares of Disaggregated Product Categories

8. Growth of Major Manufacturing Export Categories by Geographic Group, 1990-2005

9. Top Two Markets and Suppliers of Major Manufacturing Exports, 2005

10. Coefficients on Selected Variables from the Global Gravity Model

11. Undertrading in Developing Countries, 2000-05

12. Undertrading in Sub-Saharan Africa, 2000-05

A1. Export Shares of Major Product Categories, 1995 and 2005

A2. Subgroups of Countries

Figures

1. Share of World Trade by Region, 1970-2005

2. Total Merchandise Exports by Destination, 1985 and 2005

$\underline{2}$

3. Destination Shares of Sub-Saharan African Exports, 1990 and 2005

4. Exports of Major Merchandise Categories, 1985-2005

5a. Oil Importers: Fuel Share of Total Imports, 1995-2005

5b. Oil Importers: Growth of Fuel and Total Imports, 1995-2005

6. Sub-Saharan African Import Shares for Selected Products and Trade Partners, 1990 and 2005

7. Fastest-Growing Major Product Categories by Geographic Group

8. Sub-Saharan Africa: Undertrading by Geographic Subgroup, 2000-05

9. Selected Economies: Major Product Category Shares of Total Exports

A1a. Selected Economies: Food and Beverage

A1b. Selected Economies: Crude Inedible Materials

A1c. Selected Economies: Manufacturing Share of Total Exports

A1d. Selected Economies: Fuels Share of Total Exports 


\section{Abbreviations}

ACP African, Caribbean, and Pacific

AGOA Africa Growth and Opportunity Act

ATC Agreement on Textiles and Clothing (WTO)

CEMAC Communauté Économique et Monétaire de l'Afrique Centrale

(Central African Economic and Monetary Community)

CNOOC China National Offshore Oil Corporation

COMESA Common Market for Eastern and Southern Africa

EBA Everything But Arms initiative (European Union)

ECOWAS Economic Community of West African States

EIA U.S. Energy Information Administration

EU European Union

GEPetrol National Oil Company of Equatorial Guinea

GSP Generalized System of Preferences (WTO)

ISO International service outsourcing

LAC Latin America and the Caribbean

MENA Middle East and North Africa

MFN Most-favored-nation

PRGF Poverty Reduction and Growth Facility (IMF)

RTA Regional trade agreements

SADC Southern African Development Community

SITC Standard International Trade Classification

WTO World Trade Organization 
This page intentionally left blank

(C) International Monetary Fund. Not for Redistribution 


\section{Preface}

Sub-Saharan Africa's share in world trade has been declining since the 1970s. The growth in many emerging economies in Asia, in particular China, and the associated increased demand for commodities is creating opportunities for the region to reverse this decline and to use trade to promote growth and reduce poverty. This paper examines shifts in sub-Saharan Africa's trade with different regions since 1985 as well as changes in its composition, including trade in manufactured goods. It also presents estimates on the extent to which sub-Saharan Africa is exploiting its trade potential, using a benchmark model. This is followed by an analysis of the impediments to trade that are specific to the region, and suggestions to tackle these in order to make trade an engine of growth.

An earlier, shorter version of this paper's material appeared in the April 2007 issue of the Regional Economic Outlook: Sub-Saharan Africa. The authors wish to thank Benedicte Christensen, Arvind Panagriya, Volker Treichel, Dmitry Gershenson, and Yongzheng Yang for their guidance and help in preparing this paper, and Axel Palmason, Stephen Tokarick, Brad McDonald, Felix Eschenbach, Caroline Freund, Zhiwei Zhang, and Nuno Limão for helpful comments. They are grateful to Gustavo Ramirez for research assistance, Anne Grant for editorial assistance, Emma Morgan for production of the document, and Marina Primorac for coordinating production of the printed publication. 
This page intentionally left blank

(C) International Monetary Fund. Not for Redistribution 


\section{CHAPTER}

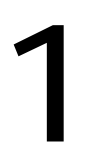

\section{Overview}

Sub-Saharan Africa's share in global trade (exports plus imports) has declined from about 4 percent in 1970 to about 2 percent at present (Figure 1). This long-term decline is traceable to such factors as macroeconomic instability, high and cascading tariff structures, and unfavorable cost structures as a result of poor business environments, small domestic markets, and high indirect costs (Gupta and Yang, 2006).

However, the region's trade prospects have improved with the recent commodity boom. Because it is well endowed with natural resources, subSaharan Africa has benefited from the boom, which has reoriented its trade toward rapidly growing economies. China accounted for about 20 percent of the increase in global oil imports between 2000 and 2004 and about 15 percent of the increase in metallic ore imports (Goldstein and others, 2006). The effect of India is estimated to be smaller, although India accounted for nearly one-third of the increase in global imports of precious stones between 2000 and 2004. In each case, sub-Saharan African producers of these commodities have seen major export surges.

Continued rapid growth in Asia offers sub-Saharan Africa opportunities to reverse the long-term decline in its trade share. Because most domestic markets in sub-Saharan Africa are small, exports to Asia offer sub-Saharan African producers opportunities to vastly expand their markets. There is evidence that sub-Saharan African firms become more productive when they export ("learning by exporting"), so an upturn in exports could help lay the foundation for sustained growth (Bigsten and Söderbom, 2006). ${ }^{1}$ In principle, African producers may find opportunities for diversification as labor costs in East Asia increase, shifting cost advantages toward sub-Saharan Africa, and as demand changes with growth of the middle class in China and India (Winters and Yusuf, 2007). Moreover, efforts to improve the business

\footnotetext{
${ }^{1}$ See also Mengistae and Pattillo (2004). However, there is little evidence that the textile export boom in subSaharan Africa under the U.S. Africa Growth and Opportunity Act led to increases in productivity (World Bank, 2004); the learning-by-exporting effect may need supporting factors to be effective. See also the discussion in Chapter 4.
} 
Figure 1. Share of World Trade

by Region, 1970-2005

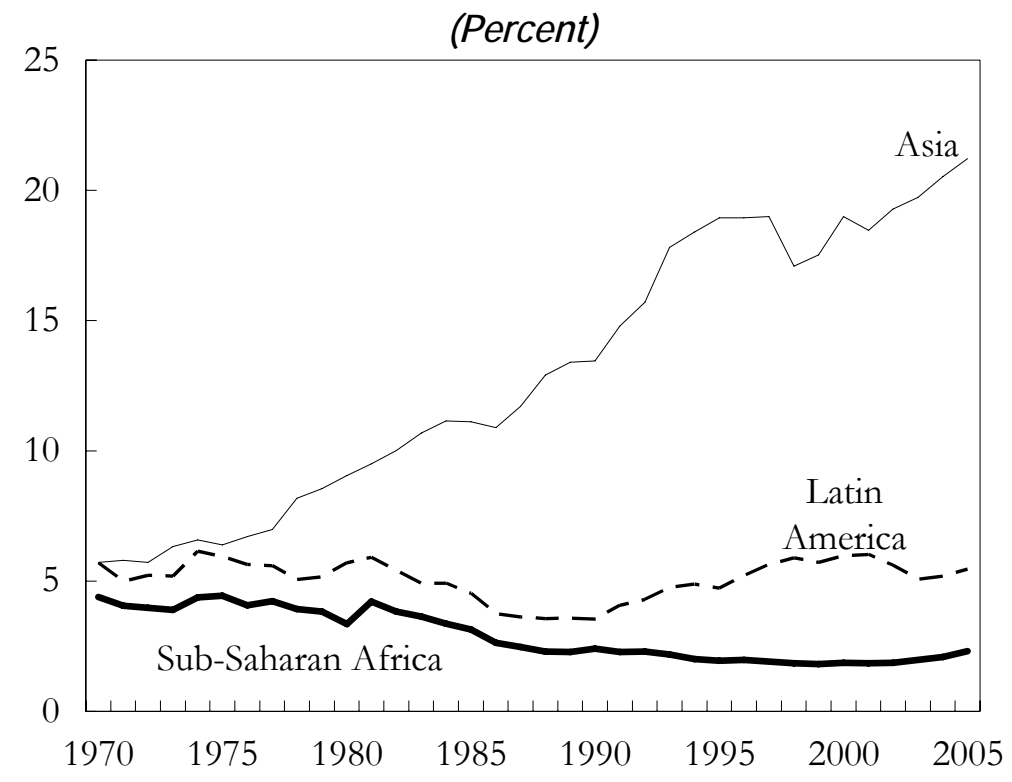

Source: IMF, Direction of Trade Statistics.

environment in sub-Saharan Africa could make it possible for countries there to exploit untapped potential in traditional export destinations.

This study analyzes the trade patterns emerging in sub-Saharan Africa and assesses their implications for policy. Whereas recent studies (World Bank, 2004; Goldstein and others, 2006; and Broadman, 2007) highlight growing trade between sub-Saharan Africa and Asia, this study looks at all sub-

Saharan Africa's trading partners, including industrial countries (Chapter 2). Other studies have treated the countries in sub-Saharan Africa as a homogenous group; however, this study differentiates among them on the basis of endowments (resource-intensive or not) and location (coastal or landlocked) to assess whether these considerations are relevant to trade. The study also analyzes merchandise trade in terms of product groups that are gaining acceptance in industrial and fast-growing emerging economies and whether in the aggregate the region is undertrading or overtrading (Chapter 3). It concludes with suggestions for policies that would help sub-Saharan Africa realize its full trade potential (Chapter 4). 


\section{Evolution of Sub-Saharan African Trade Patterns through 2005}

\section{Trade Patterns by Destination}

The share of sub-Saharan Africa's exports to developing countries has more than doubled since 1990. As Asia industrializes, its demand for natural resources increases. Sub-Saharan Africa has responded to this new export opportunity, and Asia now receives about 25 percent of sub-Saharan Africa's exports. China and India together account for about 10 percent of both exports from and imports to sub-Saharan Africa-25 percent more than the share of these two countries in world trade (Broadman, 2007).

Economic relations between China and sub-Saharan Africa have expanded enormously in recent years (Box 1). In 2005, the most recent year for which data are available, sub-Saharan African exports to China amounted to $\$ 19.2$ billion, compared with negligible levels in 1990 and some $\$ 5$ billion in 2000. They have grown by 30 percent annually since 2000 and account for about 20 percent of sub-Saharan Africa's total export growth during that period. Fuel accounted for about 70 percent of total sub-Saharan Africa exports to China in 2005. To put this in global perspective, China imported $\$ 64.4$ billion worth of fuel from the world as a whole in 2005 , of which $\$ 13.3$ billion came from sub-Saharan Africa. Thus, sub-Saharan Africa accounted for 20.7 percent of all Chinese fuel imports. As a percentage of total Chinese imports, sub-Saharan Africa accounts for 2.9 percent. Sub-Saharan African imports from China have also surged, from $\$ 3.5$ billion in 2000 to more than $\$ 13$ billion in 2005 .

This expansion in economic relations with China is not unique to subSaharan Africa. In fact, there has been rapid growth in China's trade with many developing and developed countries. For example, India's imports from China grew from extremely low levels in 1990 to nearly $\$ 11$ billion in 2005-06; its exports to China were about $\$ 7$ billion in 2005-06, again up from minuscule levels in 1990. Imports to the European Union from China doubled between 2000 and 2005, when, at about $€ 160$ billion, they were 


\section{Box 1. China's Financial Relations with Sub-Saharan Africa}

China's financial assistance to sub-Saharan Africa is substantial. Loans and credit lines are estimated at about $\$ 19$ billion, and in October 2006 at the Beijing Summit, China announced assistance of about $\$ 5$ billion. The beneficiaries of the largest flows are Angola, Equatorial Guinea, Gabon, the Republic of Congo, and Nigeria; Angola and Equatorial Guinea alone have credit lines totaling about $\$ 14$ billion. The share of grants is small, but China recently cancelled an estimated $\$ 260$ million in debt for the Democratic Republic of the Congo, Ethiopia, Guinea, Mali, Rwanda, Senegal, Togo, and Uganda.

The concessionality of the loans varies widely. ${ }^{1}$ Some large loans and credit lines have not been fully concessional, although their terms are more favorable than those of the market. However, a recent $\$ 2$ billion credit line to Equatorial Guinea and numerous smaller loans to sub-Saharan African countries are concessional. The degree of concessionality is also affected by the requirement that only Chinese companies using Chinese products bid on the projects (70 percent of Chinese credit lines in Angola have been used this way). In addition, repayment of loans has sometimes been tied (as in Angola) to the supply of oil.

China's aid to sub-Saharan African countries is aimed largely at financing projects in energy, telecommunications, and transportation. It is often accompanied by deals to develop mining and energy resources. For example, in the Republic of Congo, in return for the right to explore and exploit natural resources, China is helping build transportation, energy, telecommunications, and water facilities and is providing support for social sectors. However, China's activities in construction and infrastructure predate its interest in resource-linked investments; Chinese construction companies were the first to enter Africa. For example, China was involved with the Tanzania-Zambia railway when it was constructed in the 1970s.

Chinese state-owned companies often enter into joint ventures with sub-Saharan African stateowned companies in resource-based projects. The Chinese company SINOPEC has invested $\$ 3.5$ billion in a partnership with the Angolan Sonangol to pump oil from recently auctioned offshore blocks. SINOPEC has also announced its intention to build a $\$ 3$ billion refinery in Angola. In Gabon, the CMEC/Sinosteel consortium—financed by the Chinese Export-Import Bank-is investing about $\$ 3$ billion in exploiting iron ore deposits; it is constructing a railway, a port, and a hydroelectric power station in return for exclusive rights to develop the mine. And a subsidiary of the China National Offshore Oil Corporation (CNOOC) recently signed a production-sharing contract with the National Oil Company of Equatorial Guinea (GEPetrol). However, joint ventures in construction are rare.

${ }^{1}$ Loans are generally considered concessional if they have a minimum grant element of 35 percent, based on reference commercial interest rates published by the Organization for Economic Cooperation and Development.

almost as high as EU imports from the United States. ${ }^{2}$ Sub-Saharan Africa is unusual in global terms in that it runs a trade surplus with China, because its

${ }^{2}$ The data on EU-China trade come from Eurostat and reflect a 25-member European Union. 
resource abundance is a key driver of the trade relationship. In this regard sub-Saharan Africa most resembles Latin America, where exports to China are also concentrated in primary products, whereas imports are predominantly manufactured (Moreira, 2007).

Nevertheless, China has placed special emphasis on a multifaceted relationship with sub-Saharan Africa, encompassing trade, aid, and financial flows. At the Beijing Summit of the Forum on China-Africa Cooperation, President $\mathrm{Hu}$ Jintao announced that by 2009 China would double its 2006 assistance to Africa; provide $\$ 5$ billion in preferential credits and the same amount in a China-Africa Development Fund to encourage and support investment by Chinese companies in Africa; cancel all interest-free government loans due at end-2005 owed by heavily indebted poor countries and least developed countries in Africa that have diplomatic relations with China; improve market access; and provide assistance in social sectors, for example, by training African professionals, building hospitals and schools, and funding malaria prevention and treatment. In addition, commercial contracts worth $\$ 1.9$ billion were concluded in various sectors, and the intention to more than double bilateral trade to $\$ 100$ billion by 2010 was announced. Though the attitude toward China's active role is generally favorable in Africa, there have been points of controversy, such as textile imports and labor conditions (McLeary, 2007).

Even though Asia's importance to sub-Saharan Africa has been increasing, the European Union and the United States are still its largest trading partners (Figure 2). Although sub-Saharan African exports to China have grown rapidly_-by 260 percent cumulatively between 2000 and 2005-and China is now sub-Saharan Africa's single largest trading partner in Asia, there has also been substantial growth in exports to traditional sub-Saharan African destinations.

Exports to the EU-153 grew by 66 percent between 2000 and 2005, and those to the United States grew by 112 percent. Merchandise exports to China of about $\$ 19$ billion in 2005 are dwarfed by exports to the EU-15 of $\$ 56$ billion and to the United States of $\$ 52$ billion. ${ }^{4}$ The share of the United States and the European Union is still two-and-a-half times that of Asia and almost six times that of China (Figure 3).

\footnotetext{
${ }^{3}$ The EU-15 includes Austria, Belgium, Denmark, Finland, France, Germany, Greece, Ireland, Italy, Luxembourg, the Netherlands, Portugal, Spain, Sweden, and the United Kingdom.
}

${ }^{4}$ It would be useful to break down the growth in export values into price and volume components, but this task is extremely complex, because it would require disaggregated price data for each exporting country. 
Figure 2. Total Merchandise Exports by

Destination, 1985 and 2005

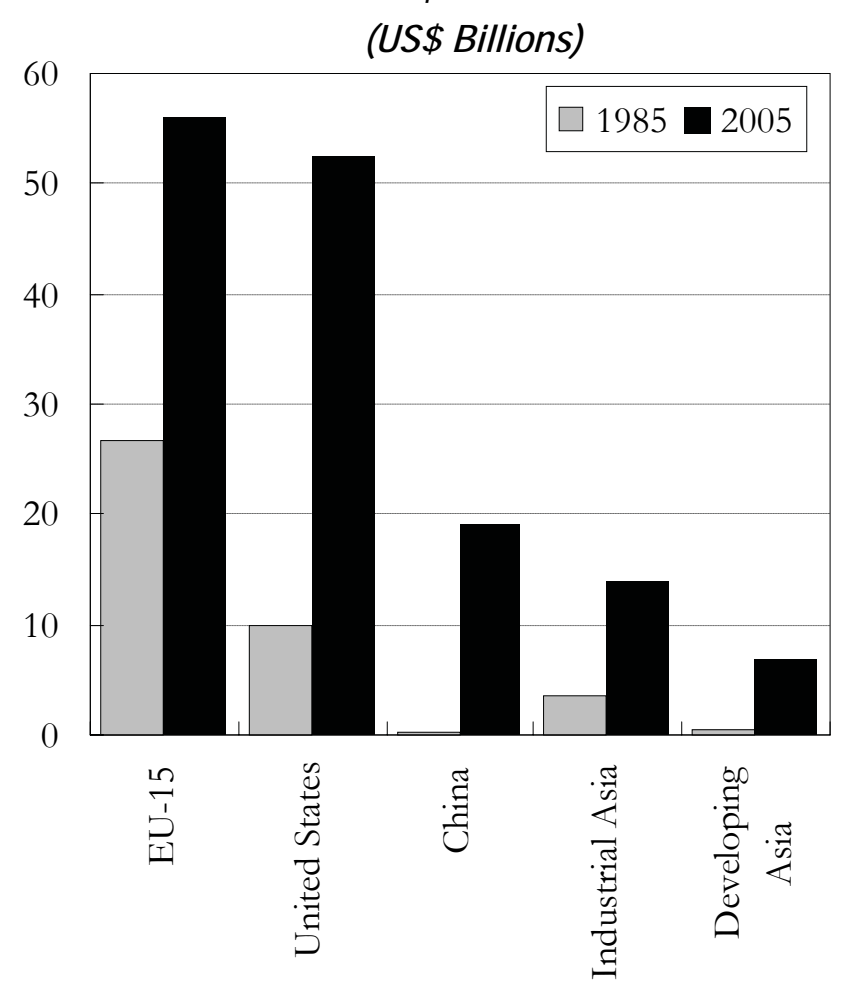

Source: UN Comtrade.

\section{Trade Patterns by Product}

Fuel explains much of sub-Saharan Africa's export surge in value terms (Figure 4). Total sub-Saharan African exports rose by just over 75 percent between 1985 and 2000 — an annual rate of about 5 percent. They have since grown by another 75 percent, tripling the annual growth rate for 2000-05 to nearly 15 percent. Oil exports alone increased by more than $\$ 20$ billion between 2004 and 2005. Of the total increase in export values between 2000 and 2005, fuels accounted for 65 percent, manufactures 24 percent, and food and raw materials about 5 percent each. Because manufactures include processed natural resources, the extent to which sub-Saharan Africa's export boom is resource-driven is obvious.

There is limited evidence of product diversification in the export pattern. In fact, the share of fuels has risen to more than half of total sub-Saharan African exports (Table 1), with annual increases of more than 40 percent in both 2004 and 2005 (Table 2). Food and beverages and raw materials have 


\section{Figure 3. Destination Shares of Sub-Saharan African}

\section{Exports, 1990 and 2005}

(Percent)
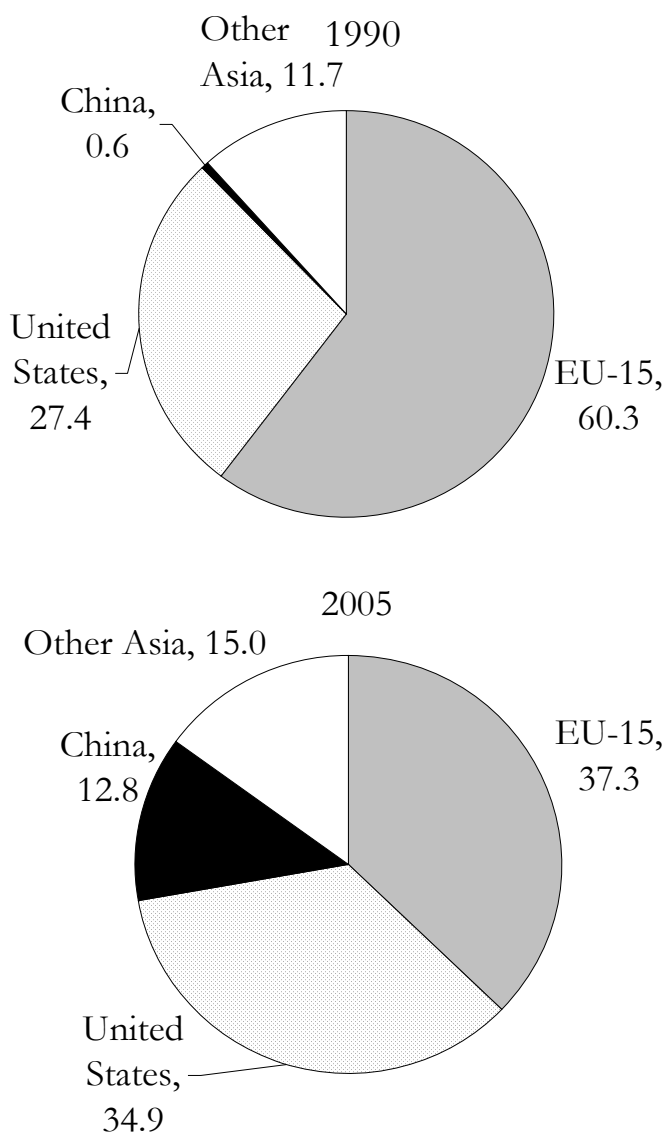

Sources: UN Comtrade; and IMF staff calculations.

seen long-term declines, though the share of manufactures has grown since 1985; the upward trend is obscured for 2005 by the large increase in oil exports.

The emergence of China as an important trade partner for sub-Saharan Africa is most pronounced for fuels and raw materials (Table 3). From a small percentage in 1990, China's share increased to one-fourth of raw materials and one-sixth of fuels in 2005. The share of fuel exports to the United States also rose by a few percentage points. The increases came from a reduction in the EU-15 share. Trade patterns for food and beverages hardly changed between 1990 and 2005. 
Figure 4. Exports of Major Merchandise Categories, 1985-2005

(Selected years; values in US\$ billions)

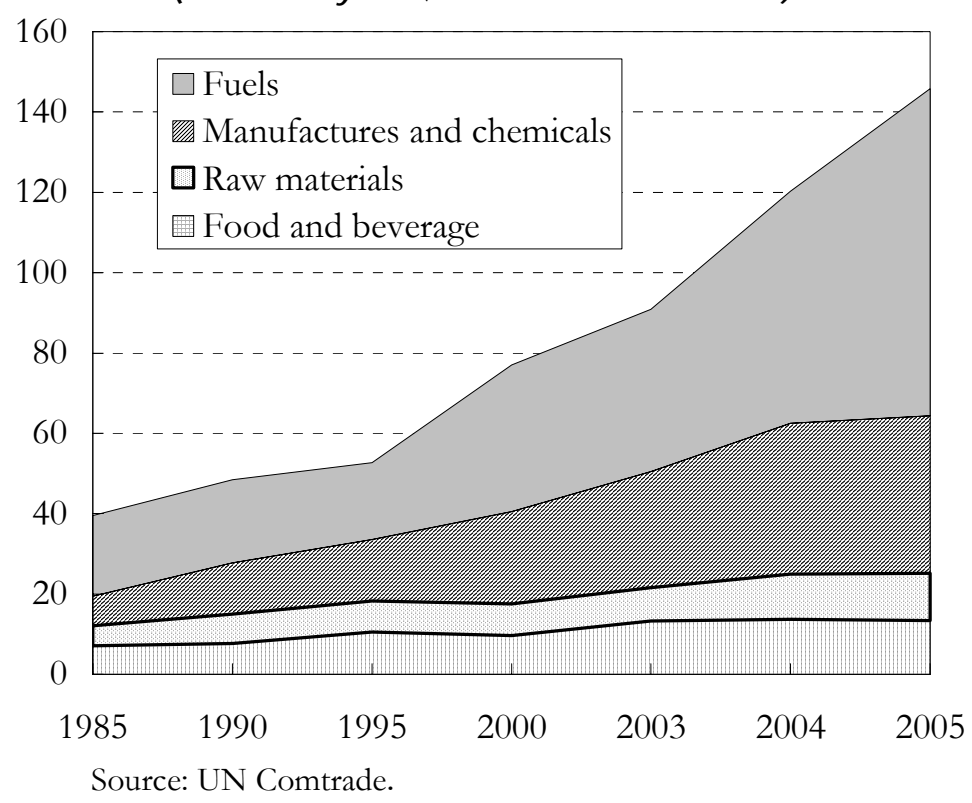

Table 1. Sectoral Composition of Exports (Percent)

\begin{tabular}{lcccccc}
\hline & 1985 & 1990 & 1995 & 2000 & 2004 & 2005 \\
\hline Food and beverages & 18.3 & 16.1 & 20.1 & 12.5 & 11.3 & 9.1 \\
Raw materials & 12.3 & 14.9 & 14.5 & 10.2 & 9.2 & 7.9 \\
Fuels & 50.0 & 41.8 & 35.9 & 46.9 & 47.6 & 54.9 \\
Manufactures and chemicals & 18.6 & 26.0 & 28.6 & 29.6 & 31.0 & 26.4 \\
\hline
\end{tabular}

Source: UN Comtrade.

Asia's share in sub-Saharan African manufacturing exports grew only moderately (by about 8 percentage points), mainly from increased Chinese demand. The U.S. share also increased somewhat because of the Africa Growth and Opportunity Act (AGOA). Again, the EU-15 share declined, though Europe still accounts for more than half of sub-Saharan African manufacturing exports, followed by the United States and industrial Asia; exports to other Asian partners are small. 
Table 2. Growth Rates of Broad Export Categories

(Annualized percentage growth of nominal trade values)

\begin{tabular}{lcccccc}
\hline & $1985-90$ & $1990-95$ & $1995-2000$ & $2000-03$ & $2003-04$ & $2004-05$ \\
\hline Food and beverages & 1.6 & 7.1 & -1.9 & 12.2 & 3.3 & -1.7 \\
Raw materials & 9.7 & 1.1 & 0.4 & 1.9 & 34.3 & 4.6 \\
Fuels & 0.6 & -1.4 & 18.1 & 3.7 & 42.6 & 41.0 \\
$\quad \begin{array}{l}\text { Manufactures and } \\
\quad \text { chemicals }\end{array}$ & 14.4 & 3.9 & 10.1 & 8.4 & 30.5 & 4.2 \\
$\quad$ Total & 4.0 & 1.9 & 9.2 & 5.9 & 32.2 & 22.2 \\
\hline
\end{tabular}

Source: UN Comtrade.

Note: The total includes Standard International Trade Classification (SITC) 9, which covers certain special items - notably arms — that are not included in the listed sectoral categories.

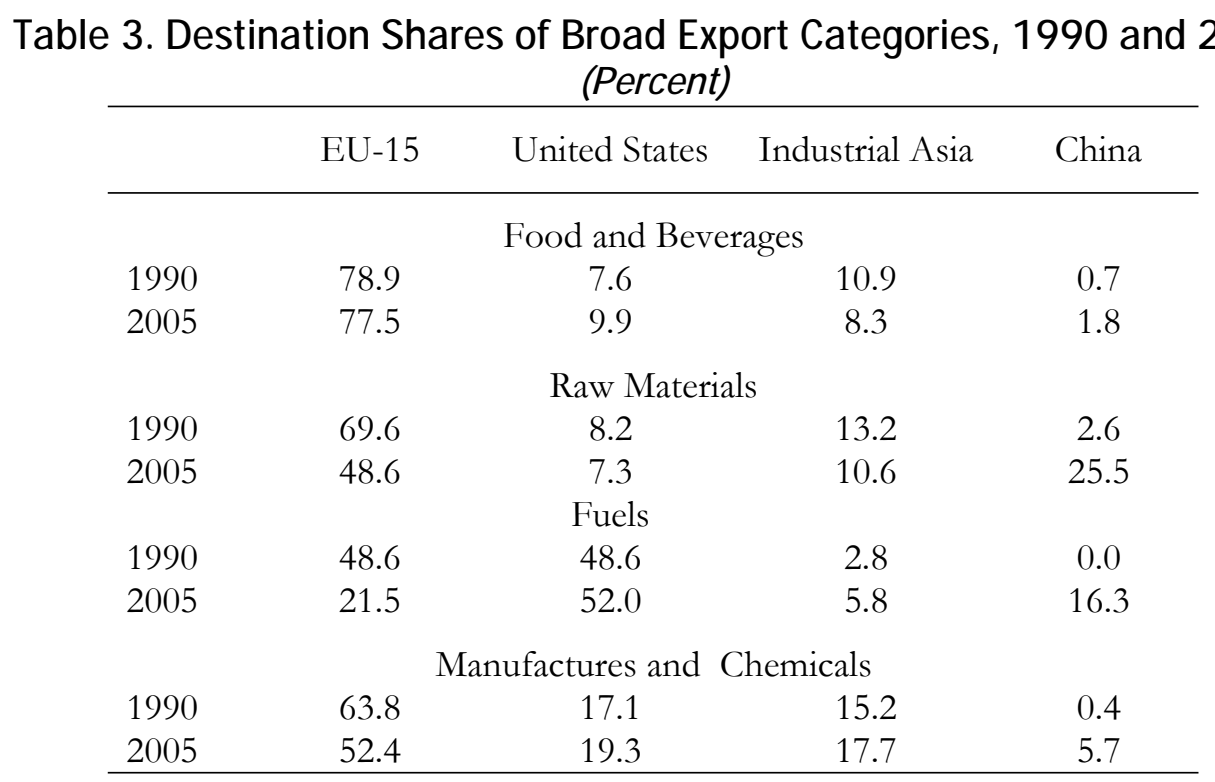

Source: UN Comtrade.

The dependence of sub-Saharan African nonfuel exports on agricultural commodities has declined and that of certain resource-linked manufacturing products has increased (see Appendix Table A1). Manufactured exports accounted for nearly 60 percent of all nonfuel exports in 2005, up from 37 percent in 1985. Within manufacturing, the major categories are precious stones, whose share has more than tripled since 1985, and silver and platinum, whose share has nearly doubled. Iron, aluminum, clothing, and vehicles are the other major product categories. By contrast, the share of most nonmanufacturing categories, especially coffee and cocoa, declined. Among the exceptions are the shares of fruit and nuts and fish, but together these account for just over 6 percent of nonfuel exports. 
The evidence is mixed on whether the recent growth improvement in subSaharan African is associated with higher exports, including those of manufactures. Sub-Saharan Africa's oil importers on average saw an increase in annual growth of about 2 percent between 2000 and 2005 and an increase of about 2 percentage points in the exports-to-GDP share over the same period. ${ }^{5}$ However, the relationship is somewhat weaker at the country level. Whereas fast growers like Tanzania, Zambia, Ethiopia, and Kenya have higher export shares, other countries, such as Ghana and Namibia, have grown while the export shares declined. Furthermore, some countries (for example, Lesotho and Swaziland) have seen sizable increases in export shares without any surge in growth. Similarly, there is no clear relationship between growth and an increased share of manufactures in total exports. Several countries (concentrated in southern Africa) have registered large increases in the share of manufactured exports, but others (Ethiopia, Tanzania, and Uganda) are growing rapidly with shares at 15 percent or less.

\section{Export Patterns by Sub-Saharan African Country Grouping}

It is often argued that trade patterns are influenced by geography, as are growth prospects generally (Gallup, Sachs, and Mellinger, 1998). In this section, countries are classified as resource-intensive, with subgroups oil and non-oil; and non-resource-intensive, with subgroups coastal and landlocked. These groupings follow Collier and O'Connell (2007). A country is classified as resource-intensive if primary commodity rents — that is, revenue minus extraction costs - exceed 10 percent of GDP. In terms of location, countries are classified by whether they have ocean access (coastal) or are landlocked. A country is classified as landlocked if its access to the ocean is limited and the limited access is likely to be a significant impediment to trade. ${ }^{6}$

Although the destination of exports of sub-Saharan Africa's oil-producing countries is changing, those exports have become even more concentrated in fuels (Table 4, top panel). Since 1990, the share of fuels in total exports of the oil-producing countries has increased by about 12 percentage points, to almost 90 percent. The EU-15 share in oil exports fell by more than half, to about 20 percent; Asian destinations expanded their share to 23 percent; and the U.S. share rose by more than 5 percentage points, to 58 percent. In other product groups, the EU-15 is still the largest destination, although its share has declined in favor of the United States (mainly in manufacturing and food

\footnotetext{
${ }^{5}$ The calculation compares average growth and export shares in 2004-06 with 1999-2001, to smooth out single-year fluctuations in 2000 and 2005.

${ }^{6}$ For example, the Democratic Republic of the Congo is classified as landlocked. See also Appendix 1.
} 
Table 4. Merchandise Exports by Geographic Grouping, Destination, and Product, 1990 and 2005 (Percent)

\begin{tabular}{|c|c|c|c|c|c|c|}
\hline Destination & Year & $\begin{array}{c}\text { Raw } \\
\text { Materials }\end{array}$ & $\begin{array}{l}\text { Food and } \\
\text { Beverages }\end{array}$ & Fuels & $\begin{array}{l}\text { Manu- } \\
\text { factures }\end{array}$ & Total \\
\hline & \multicolumn{6}{|c|}{ Oil Producers } \\
\hline \multirow[t]{2}{*}{ EU-15 } & 1990 & 78.4 & 87.6 & 46.9 & 94.2 & 55.5 \\
\hline & 2005 & 56.0 & 76.6 & 19.2 & 74.1 & 24.3 \\
\hline \multirow[t]{2}{*}{ United States } & 1990 & 2.7 & 10.5 & 52.1 & 4.7 & 42.0 \\
\hline & 2005 & 4.9 & 19.5 & 57.8 & 15.6 & 53.4 \\
\hline \multirow[t]{2}{*}{ Asia } & 1990 & 18.9 & 1.8 & 1.4 & 1.1 & 2.5 \\
\hline & 2005 & 39.1 & 3.8 & 23.0 & 10.3 & 22.3 \\
\hline \multirow[t]{2}{*}{ Of which: China } & 1990 & 3.5 & 0.2 & 0.4 & 0.4 & 0.3 \\
\hline & 2005 & 29.5 & 0.5 & 14.7 & 2.7 & 14.2 \\
\hline \multirow[t]{3}{*}{ Product share of total exports } & 1990 & 7.9 & 9.2 & 77.9 & 4.9 & $\ldots$ \\
\hline & 2005 & 3.3 & 4.7 & 89.7 & 2.1 & $\ldots$ \\
\hline & \multicolumn{6}{|c|}{ Coastal } \\
\hline \multirow[t]{2}{*}{ EU-15 } & 1990 & 68.2 & 76.5 & 73.2 & 59.6 & 66.6 \\
\hline & 2005 & 43.3 & 79.6 & 91.7 & 47.5 & 56.0 \\
\hline \multirow{2}{*}{ Excluding South Africa } & 1990 & 74.7 & 77.6 & 54.0 & 67.9 & 72.6 \\
\hline & 2005 & 45.2 & 84.0 & 32.9 & 75.5 & 73.4 \\
\hline Asia & 1990 & 23.1 & 18.4 & 23.6 & 17.5 & 19.5 \\
\hline \multirow[t]{2}{*}{ Excluding South Africa } & 1990 & 19.1 & 15.1 & 5.6 & 20.8 & 18.0 \\
\hline & 2005 & 46.2 & 11.9 & 2.7 & 4.9 & 14.1 \\
\hline Of which: China & 1990 & 0.4 & 0.4 & 0.2 & 0.4 & 0.5 \\
\hline \multirow{2}{*}{ Excluding South Africa } & 1990 & 2.8 & 0.4 & 3.6 & 1.3 & 1.3 \\
\hline & 2005 & 32.4 & 1.1 & 0.0 & 0.2 & 5.6 \\
\hline \multirow{2}{*}{ Product share of total exports } & 1990 & 20.5 & 23.1 & 9.0 & 45.0 & $\ldots$ \\
\hline & 2005 & 12.8 & 14.6 & 7.6 & 60.6 & $\ldots$ \\
\hline \multirow[t]{3}{*}{ Excluding South Africa } & 1990 & 18.1 & 38.1 & 1.3 & 39.6 & $\ldots$ \\
\hline & 2005 & 15.7 & 38.7 & 0.9 & 43.7 & $\ldots$ \\
\hline & \multicolumn{6}{|c|}{ Landlocked } \\
\hline \multirow[t]{2}{*}{ EU-15 } & 1990 & 62.7 & 74.8 & 9.8 & 77.3 & 70.6 \\
\hline & 2005 & 34.3 & 69.8 & 33.7 & 48.1 & 50.0 \\
\hline \multirow[t]{2}{*}{ United States } & 1990 & 4.1 & 13.2 & 90.2 & 10.5 & 15.0 \\
\hline & 2005 & 2.0 & 12.2 & 59.5 & 38.0 & 23.2 \\
\hline \multirow[t]{2}{*}{ Asia } & 1990 & 33.2 & 12.1 & 0.0 & 12.3 & 14.4 \\
\hline & 2005 & 63.8 & 18.0 & 6.8 & 13.9 & 26.8 \\
\hline \multirow[t]{2}{*}{ Of which: China } & 1990 & 3.1 & 3.0 & 0.0 & 0.7 & 1.6 \\
\hline & 2005 & 40.1 & 8.4 & 0.0 & 1.7 & 13.0 \\
\hline \multirow[t]{2}{*}{ Product share of total exports } & 1990 & 14.4 & 27.5 & 4.8 & 49.9 & $\ldots$ \\
\hline & 2005 & 27.6 & 27.6 & 6.0 & 40.5 & $\ldots$ \\
\hline
\end{tabular}

Source: UN Comtrade. 
and beverages) and Asia (mainly in raw materials ${ }^{7}$ and to a lesser extent manufactures).

Coastal countries are highly dependent on exports to the EU-15, particularly of manufactures (Table 4, middle panel), which since 1990 have risen to about 60 percent of total exports. The EU-15 is still the dominant destination for all export categories, though in manufactures and raw materials exports its share and that of the United States have declined, mostly because of increased demand from Asia. Coastal countries other than South Africa are even more dependent on the European Union and export nearly the same quantity of food and beverages as manufactures; for this group, since 1990 the share of manufactures is up by only 4 percentage points.

Landlocked countries are also dependent on the European Union, but Asia is becoming more important to them as a trading partner (Table 4, bottom panel). Compared with coastal countries, their exports are less concentrated in manufactures; raw materials and food and beverages have substantial shares, which have been steady or higher since 1990 as the share of manufactured exports has declined. The United States in recent years joined the EU-15 as a dominant export destination for manufactures because of its growing textile imports under AGOA. China and other Asian countries replaced the European Union as the main destination for raw-material exports, principally raw cotton. Nevertheless, the trade pattern for coastal and landlocked countries is still heavily influenced by the traditional mode of exporting raw commodities to industrial countries. The global trade regime facing sub-Saharan Africa features much less tariff escalation than in the past, owing in part to extensions of the Generalized System of Preferences, such as AGOA and the European Union's Everything But Arms (EBA) initiative. However, a variety of constraints mitigate the impact of these liberalizing measures, lending persistence to the historic trade pattern (see Chapter 4).

\section{Sub-Saharan Africa's Import Pattern}

Several aspects of sub-Saharan Africa's import pattern are of interest, including the fuel share, increased orientation toward Asia, and the role of manufactured imports. As global oil prices surged, there was a concern that higher fuel import bills would squeeze other imports in low-income countries. One cushioning factor was the continued decline in the relative price of manufactures, of which the region is a net importer. This reflects the emergence of East Asia as an exporter of low-cost manufactured goods.

${ }^{7}$ Examples of raw-material exports are cotton, flowers, and wood. 
Figure 5a. Oil Importers: Fuel Share of

Total Imports, 1995-2005

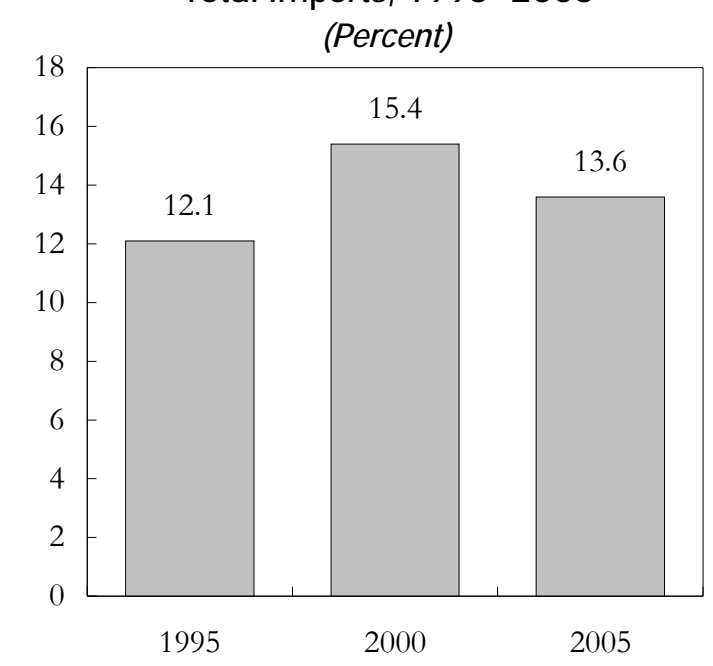

Figure 5b. Oil Importers: Growth of Fuel and Total Imports, 1995-2005

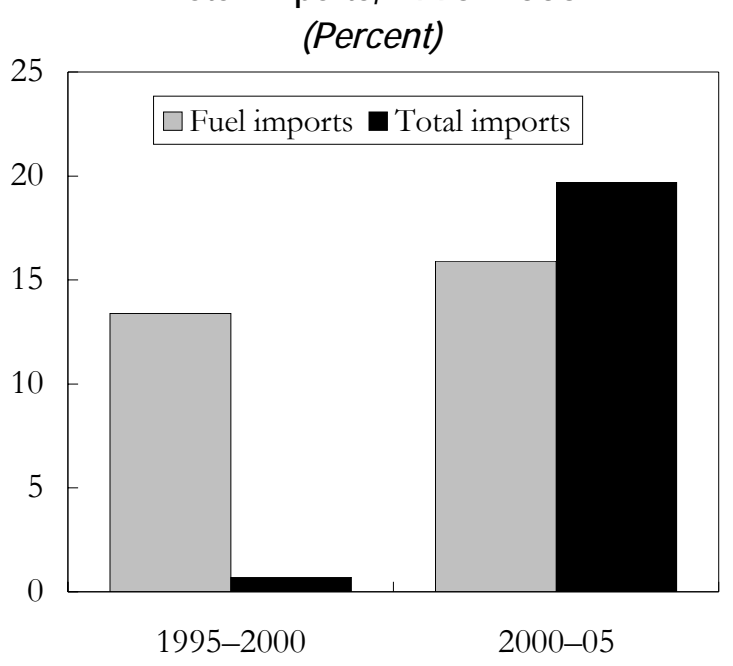

Source: UN Comtrade.

From a growth perspective, the composition of manufactured imports is also of interest, because imports may be a source of embodied technical change. This is more likely for imports of machinery than consumer products. However, sub-Saharan Africa's restrictive trade regime has raised the price of imports and placed users of imported intermediate inputs and capital goods at a particular disadvantage. Recent data may reveal whether the region's improving growth prospects have been accompanied by any change in import composition.

Sub-Saharan Africa's oil importers did not see an increase in the share of fuel in total imports between 2000 and 2005, which was just under 14 percent in 2005. Though there was an increase of nearly 3 percentage points in the fuel share between 1995 and 2000, the share declined between 2000 and 2005 (Figure 5a). Another manifestation of these movements is that the growth in fuel import value far exceeded that of total imports between 1995 and 2000; between 2000 and 2005, fuel imports grew at a similar rate again, but total imports grew by nearly 20 percent over the same period (Figure $5 \mathrm{~b}$ ). The differential behavior of oil relative to total imports in the two periods is not as surprising as it might first appear. Dudine and others (2006) calculate that the oil price increase over 1998-2000 (from $\$ 13$ a barrel to $\$ 28$ ) was larger in real terms (104 percent) than the 2003-05 oil shock (77 percent). ${ }^{8}$ Furthermore, the global economy met the prior shock with lower growth

${ }^{8}$ Real price changes are based on the U.S. consumer price index. 
(4.3 percent versus 5.1 percent) and higher interest rates (5.9 percent versus 2.3 percent London Inter-Bank Offered Rate, LIBOR), whereas low-income countries met it with lower reserves (3.5 months of import cover versus 4.5 months).

The relative flatness in the fuel import share between 2000 and 2005 is consistent with previous analysis of the impact of higher oil prices, although it may also reflect gaps in the data. The response of import values will of course depend on the behavior of import volumes. Oil import volumes do show some decline in 2005, and sub-Saharan African oil importers allowed more pass-through of higher oil prices than in the past (IMF, 2006b). Nevertheless, this is probably temporary. Energy consumption is likely to continue growing; when short-term fluctuations are smoothed out, data on petroleum consumption show a steady expansion by about 2.5 percent annually from 1981 through 2004. ${ }^{9}$ U.S. Energy Information Administration (EIA) data confirm a slight decline in sub-Saharan Africa's energy intensity in 2004 compared with 2003, whereas growth increased sharply (from 3.1 to 5.2 percent for oil importers). Over the longer term, sub-Saharan Africa's energy intensity has increased in contrast with the pattern in most other parts of the world. ${ }^{10}$ China's energy intensity fell by nearly 40 percent from 1990 to 2004, a period of extremely rapid growth. Finally, oil-import data in sub-Saharan Africa are particularly unreliable because of leakage from transit trade, other customs corruption issues, and smuggling.

The relatively mild impact of higher oil prices on the composition of imports should be seen in the context of generally rising imports in this decade. Imports as a share of GDP for oil importers increased from 29 percent on average for 1997-2001 to nearly 37 percent in 2006. Meanwhile, their current account balances deteriorated by 3 percentage points, though oil imports alone explain only part of these changes. For example, IMF (2006a) found a weak relationship between current account changes and higher oil prices in 2005; about half of oil-importing countries saw a deterioration in the current account that exceeded the impact of higher oil prices. The relatively mild impact was not confined to sub-Saharan African countries. Dudine and others (2006) found that oil imports of the typical Poverty Reduction and Growth Facility (PRGF) country rose by 1.4 percent of GDP between 2003 and 2005, but exports rose by 1.7 percent of GDP and non-oil imports by 3.5 percent of GDP, suggesting that other imports were not compressed. By

\footnotetext{
${ }^{9}$ Aggregate oil import volume data show substantial variations over time, with pronounced decreases in years of relatively low oil prices $(1999,2002)$ and increases even in times of high and rising prices (2004). The data suggest that oil import volumes are mainly a function not of consumption but of anticipated prices and supply developments and of a commensurate variation of inventories.

${ }^{10}$ See Table $1 \mathrm{~b}$ in EIA (2006). These data extend only to 2004 and so do not cover the bulk of the recent oil shock.
} 
Figure 6. Sub-Saharan African Import Shares for Selected Products and Trade Partners, 1990 and 2005

(Percent)

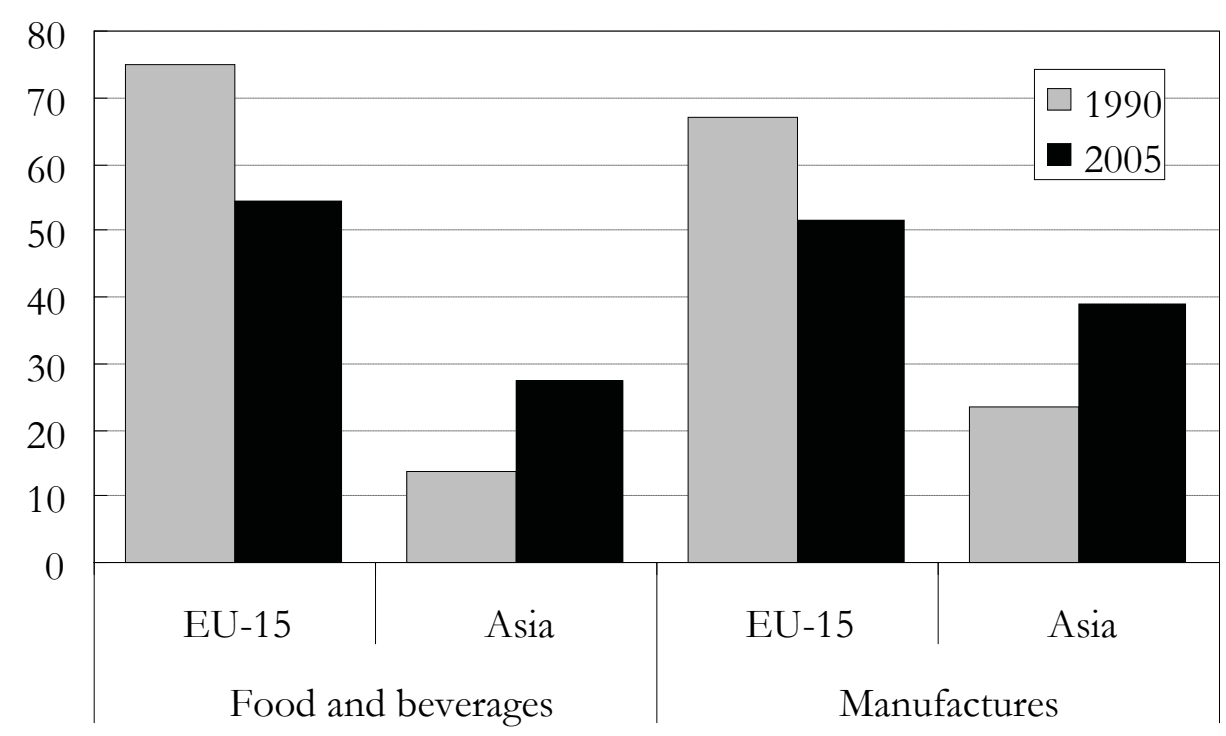

Source: UN Comtrade.

contrast, imports as a share of GDP for sub-Saharan African oil importers barely increased during the previous oil price increase from 1998 to 2000, so the increased oil import bill imposed a sharper squeeze on other imports. Sub-Saharan Africa's aggregate nonfuel imports are dominated by manufactures and food and beverages, and both have seen a shift in source away from the EU-15 toward Asia (see Figure 6). Manufactures account for about 85 percent of nonfuel imports, and food and beverages make up most of the rest. The EU share was about 50 percent for both categories in 2005 , down 15-20 percentage points from 1990_the amount by which the Asian share increased over the same period.

Nonfuel imports showed little change in product composition across geographic groups between 1990 and 2005, although there is a significant source shift from the EU-15 to China (Table 5). There is little other variation across country groups in the product shares, although oil-producing countries have a higher food and beverage share than the others. The more pronounced changes are in import sources. For oil-producing countries and landlocked countries, the EU share, which was about 75 percent in 1990, had fallen to the mid-50s by 2005. The EU share of 61.6 percent for coastal countries in 1990 fell to only about 50 percent in 2005. On the other hand, the Asian share of imports increased sharply for all groups between 1990 and 2005, with China accounting for much of the increase. The Chinese import share was up from about 1 percent in 1990 to about 13 percent for all groups in 2005. Not surprisingly, the Chinese surge is in turn attributable almost 
entirely to an increased share of sub-Saharan Africa's manufactured imports, though other Asian countries are also important sources for these products, with the overall Asian share between 30 percent and 40 percent for all groups in 2005.

Table 5. Merchandise Imports by Geographic Grouping, Destination, and Product, 1990 and 2005

(Percent of total nonfuel imports)

\begin{tabular}{|c|c|c|c|c|c|}
\hline Destination & Year & $\begin{array}{c}\text { Raw } \\
\text { Materials } \\
\end{array}$ & $\begin{array}{l}\text { Food and } \\
\text { Beverages }\end{array}$ & $\begin{array}{l}\text { Manu- } \\
\text { factures }\end{array}$ & Total \\
\hline & \multicolumn{5}{|c|}{ Oil Producers } \\
\hline \multirow[t]{2}{*}{ EU-15 } & 1990 & 71.3 & 88.4 & 71.3 & 74.1 \\
\hline & 2005 & 63.3 & 61.1 & 49.6 & 54.0 \\
\hline \multirow{2}{*}{ United States } & 1990 & 9.0 & 9.0 & 9.9 & 9.8 \\
\hline & 2005 & 14.0 & 14.8 & 12.8 & 13.4 \\
\hline \multirow[t]{2}{*}{ Asia } & 1990 & 19.7 & 3.8 & 18.7 & 16.2 \\
\hline & 2005 & 22.7 & 18.1 & 37.7 & 32.6 \\
\hline \multirow[t]{2}{*}{ Of which: China } & 1990 & 0.2 & 0.4 & 0.7 & 0.6 \\
\hline & 2005 & 4.0 & 2.5 & 15.7 & 12.9 \\
\hline \multirow{3}{*}{$\begin{array}{l}\text { Product share of total } \\
\text { nonfuel imports }\end{array}$} & 1990 & 1.1 & 14.0 & 83.6 & $\ldots$ \\
\hline & 2005 & 1.0 & 12.3 & 84.6 & $\ldots$ \\
\hline & \multicolumn{5}{|c|}{ Coastal } \\
\hline \multirow[t]{2}{*}{ EU-15 } & 1990 & 61.6 & 50.0 & 63.4 & 62.4 \\
\hline & 2005 & 46.9 & 50.0 & 51.5 & 51.5 \\
\hline \multirow[t]{2}{*}{ United States } & 1990 & 24.0 & 14.8 & 9.5 & 10.5 \\
\hline & 2005 & 17.6 & 10.0 & 9.0 & 9.3 \\
\hline \multirow[t]{2}{*}{ Asia } & 1990 & 14.4 & 24.2 & 27.1 & 27.0 \\
\hline & 2005 & 35.6 & 40.1 & 39.5 & 39.2 \\
\hline \multirow[t]{2}{*}{ Of which: China } & 1990 & 0.8 & 3.2 & 0.9 & 1.1 \\
\hline & 2005 & 6.1 & 6.1 & 14.2 & 13.0 \\
\hline \multirow{3}{*}{$\begin{array}{l}\text { Product share of total } \\
\text { nonfuel imports }\end{array}$} & 1990 & 1.9 & 6.7 & 89.9 & $\ldots$ \\
\hline & 2005 & 1.3 & 6.3 & 89.0 & $\ldots$ \\
\hline & \multicolumn{5}{|c|}{ Landlocked } \\
\hline \multirow[t]{2}{*}{ EU-15 } & 1990 & 57.3 & 81.9 & 75.4 & 75.7 \\
\hline & 2005 & 68.4 & 57.6 & 57.1 & 57.5 \\
\hline \multirow[t]{2}{*}{ United States } & 1990 & 32.6 & 13.9 & 8.4 & 9.8 \\
\hline & 2005 & 21.3 & 37.4 & 12.2 & 15.9 \\
\hline \multirow[t]{2}{*}{ Asia } & 1990 & 10.1 & 4.2 & 16.2 & 13.5 \\
\hline & 2005 & 10.3 & 5.0 & 30.6 & 30.6 \\
\hline \multirow[t]{2}{*}{ Of which: China } & 1990 & 0.0 & 1.1 & 1.3 & 1.2 \\
\hline & 2005 & 0.5 & 1.8 & 15.7 & 13.6 \\
\hline \multirow{2}{*}{$\begin{array}{l}\text { Product share of total } \\
\text { nonfuel imports }\end{array}$} & 1990 & 1.9 & 10.8 & 85.6 & $\ldots$ \\
\hline & 2005 & 1.4 & 12.9 & 82.9 & $\ldots$ \\
\hline
\end{tabular}

Source: UN Comtrade. 
Table 6. Import Shares of Major Product Categories (Percent, ranked by 2005 shares)

\begin{tabular}{lcccc}
\hline & & \multicolumn{3}{c}{ Share of Manufacturing Imports } \\
\cline { 2 - 5 } Category & Product Code & 1985 & 1995 & 2005 \\
\hline Motor vehicles & 732 & 17.7 & 15.1 & 19.6 \\
Parts for machinery and appliances & 719 & 12.2 & 11.0 & 10.0 \\
Ships and boats & 735 & 9.7 & 14.9 & 8.9 \\
Telecom equipment & 724 & 4.4 & 5.6 & 8.3 \\
Machines for mills, construction, etc. & 718 & 5.4 & 5.6 & 7.3 \\
Office machines & 714 & 3.6 & 4.3 & 4.5 \\
Aircraft & 734 & 3.1 & 2.2 & 4.1 \\
Power-generating machinery & 711 & 4.5 & 3.7 & 3.8 \\
Electrical power machinery and & & & & 3.7 \\
$\quad$ circuits & 722 & 4.5 & 3.3 & 3.0 \\
Other electrical machinery & 729 & 3.5 & 3.6 & 2.7 \\
Clothing (non-fur) & 841 & 1.4 & 2.5 & 2.0 \\
Textile yarn and fabric & 653 & 1.7 & 2.7 & 1.9 \\
Cotton fabric & 652 & 1.4 & 2.4 & 1.4 \\
Metal tools and containers & 698 & 1.5 & 1.5 & 1.3 \\
Pearls and precious stones & 667 & 0.1 & 0.3 & 1.3 \\
Tubes and pipes & 678 & 2.0 & 0.8 & 1.0 \\
Home electronics & 725 & 0.7 & 0.9 & 1.0 \\
Iron sheets & 674 & 1.7 & 1.6 & 85.8 \\
Share of above in total & & & & \\
$\quad$ manufacturing imports & & 79.4 & 82.0 & \\
\hline
\end{tabular}

Source: UN Comtrade.

Note: The categories use the three-digit Standard International Trade Classification (SITC) and are those that accounted for at least 1 percent of total sub-Saharan African manufacturing imports in 2005.

The share of capital goods (machinery and transport equipment) in subSaharan African imports has increased since 2000, and a small range of products accounts for a sizable share of such imports. This share was 36 percent in 2005, up from 32 percent in 2000; the share of such goods in China's exports to sub-Saharan Africa was also 36 percent, up from 28 percent in 2000. ${ }^{11}$ This is consistent with an increase in sub-Saharan Africa's total investment as a share of GDP over the same period.

Sub-Saharan Africa's manufacturing imports show virtually no shift toward increased shares of intermediate investment goods, except in a few specific industries. Table 6 lists the major product import categories at the three-digit level for all those that accounted for at least 1 percent of total sub-Saharan

\footnotetext{
${ }^{11}$ Capital goods are measured by total imports of Standard International Trade Classification (SITC) product 7 , which consists of machinery and transport equipment.
} 


\section{Table 7. Import Shares of Disaggregated Product Categories} (Percent, ranked by 2005 shares)

\begin{tabular}{|c|c|c|c|c|}
\hline \multirow[b]{2}{*}{ Category } & \multirow{2}{*}{$\begin{array}{l}\text { Product } \\
\text { Code }\end{array}$} & \multicolumn{3}{|c|}{ Share of Manufacturing Imports } \\
\hline & & 1985 & 1995 & 2005 \\
\hline & \multicolumn{4}{|c|}{ Oil Producers } \\
\hline Machines for mills, construction, etc. & 718 & 6.4 & 9.9 & 14.0 \\
\hline Ships and boats & 735 & 1.3 & 5.6 & 13.2 \\
\hline Motor vehicles & 732 & 18.5 & 14.7 & 12.4 \\
\hline Parts for machinery and appliances & 719 & 13.3 & 13.1 & 11.5 \\
\hline Telecom equipment & 724 & 3.4 & 4.1 & 8.6 \\
\hline \multirow[t]{2}{*}{ Electrical power machinery and circuits } & 722 & 4.9 & 4.1 & 5.3 \\
\hline & \multicolumn{4}{|c|}{ Coastal } \\
\hline Motor vehicles & 732 & 15.5 & 13.9 & 22.7 \\
\hline Parts for machinery and appliances & 719 & 11.4 & 10.5 & 9.0 \\
\hline Ships and boats & 735 & 17.5 & 19.6 & 8.8 \\
\hline Telecom equipment & 724 & 4.7 & 6.0 & 8.0 \\
\hline Office machines & 714 & 5.6 & 5.0 & 5.3 \\
\hline \multirow[t]{2}{*}{ Aircraft } & 734 & 2.0 & 1.9 & 4.8 \\
\hline & \multicolumn{4}{|c|}{ Landlocked } \\
\hline Motor vehicles & 732 & 24.6 & 24.8 & 15.8 \\
\hline Telecom equipment & 724 & 6.5 & 5.5 & 11.1 \\
\hline Aircraft & 734 & 3.2 & 2.5 & 9.7 \\
\hline Parts for machinery and appliances & 719 & 12.4 & 11.2 & 8.8 \\
\hline Machines for mills, construction, etc. & 718 & 5.7 & 7.8 & 8.4 \\
\hline Office machines & 714 & 1.7 & 3.0 & 6.1 \\
\hline \multirow[t]{2}{*}{ Textile yarn and fabric } & 653 & 1.9 & 2.3 & 5.9 \\
\hline & \multicolumn{4}{|c|}{ Non-Oil Resource-Intensive } \\
\hline Motor vehicles & 732 & 22.5 & 18.1 & 17.2 \\
\hline Machines for mills, construction, etc. & 718 & 11.6 & 9.2 & 11.1 \\
\hline Telecom equipment & 724 & 4.8 & 6.5 & 8.9 \\
\hline Parts for machinery and appliances & 719 & 16.7 & 10.8 & 8.5 \\
\hline Ships and boats & 735 & 1.2 & 0.5 & 7.3 \\
\hline
\end{tabular}

Source: UN Comtrade.

Note: The categories use the three-digit Standard International Trade Classification (SITC) (Rev. 1) and are those that accounted for at least 5 percent (approx.) of total group manufacturing imports in 2005. 
African manufacturing imports. Motor vehicle imports accounted for just under 20 percent of total imports in 2005, up 2 percentage points from 1985.

Other significant import categories are machine parts, ships, telecom equipment, aircraft, office machines and certain types of machinery, notably that used in construction and mining, paper mills, and food processing. The doubling of the share of telecom equipment between 1985 and 2005 is consistent with the emergence of cell phones, for which Africa is one of the fastest-growing markets. Cell phone subscriptions grew 60 percent annually between 1994 and 2005 (IMF, 2007). Cotton fabric, an essential input for the region's textile industry, accounts for just 2 percent of total manufacturing imports.

More disaggregated data reveal some differences in manufactured import pattern by geographic group. Table 7 lists the major product import categories at the three-digit level, indicating all those that accounted for at least 5 percent of total group manufacturing exports. Motor vehicle imports are significant in all four groupings, and highest for coastal countries at nearly 23 percent. The motor vehicle import share does not necessarily rise over time; in fact, except for the coastal groups, there is a tendency for that share to decline, whereas the share of telecom equipment increases. ${ }^{12}$ Other significant imports include aircraft, ships and boats, and certain types of machinery, notably that used in construction and mining, paper mills, and food processing. Disaggregation of the key product categories from Table 7 indicates the rising importance of imports of electrical equipment, computers, telecom equipment, and construction machinery. Looking at import values, rapid growth in telecom equipment imports is a common factor across all geographic groups (Figure 7). However, although sub-Saharan Africa may be able to reap productivity gains as a user of imported technology, the data do not show a surge in imports of machinery used for manufacturing.

\section{A Closer Look at Sub-Saharan Africa's Manufacturing Exports}

In all country groupings, sub-Saharan Africa's exports of manufactures are confined to a few product categories (Table 8). Seven industries ${ }^{13}$ account for 75-80 percent of those exports: nonferrous metals and nonmetallic mineral manufactures (mainly diamonds) each account for about 30 percent of the

\footnotetext{
${ }^{12}$ Motor vehicle imports to landlocked countries may be underrecorded if vehicles are driven across the border by owners after purchase in a coastal country.

${ }^{13}$ Based on two-digit SITC.
} 
Figure 7. Fastest-Growing Major Product Categories by Geographic Group (Annual percentage rate, 1990-2005)

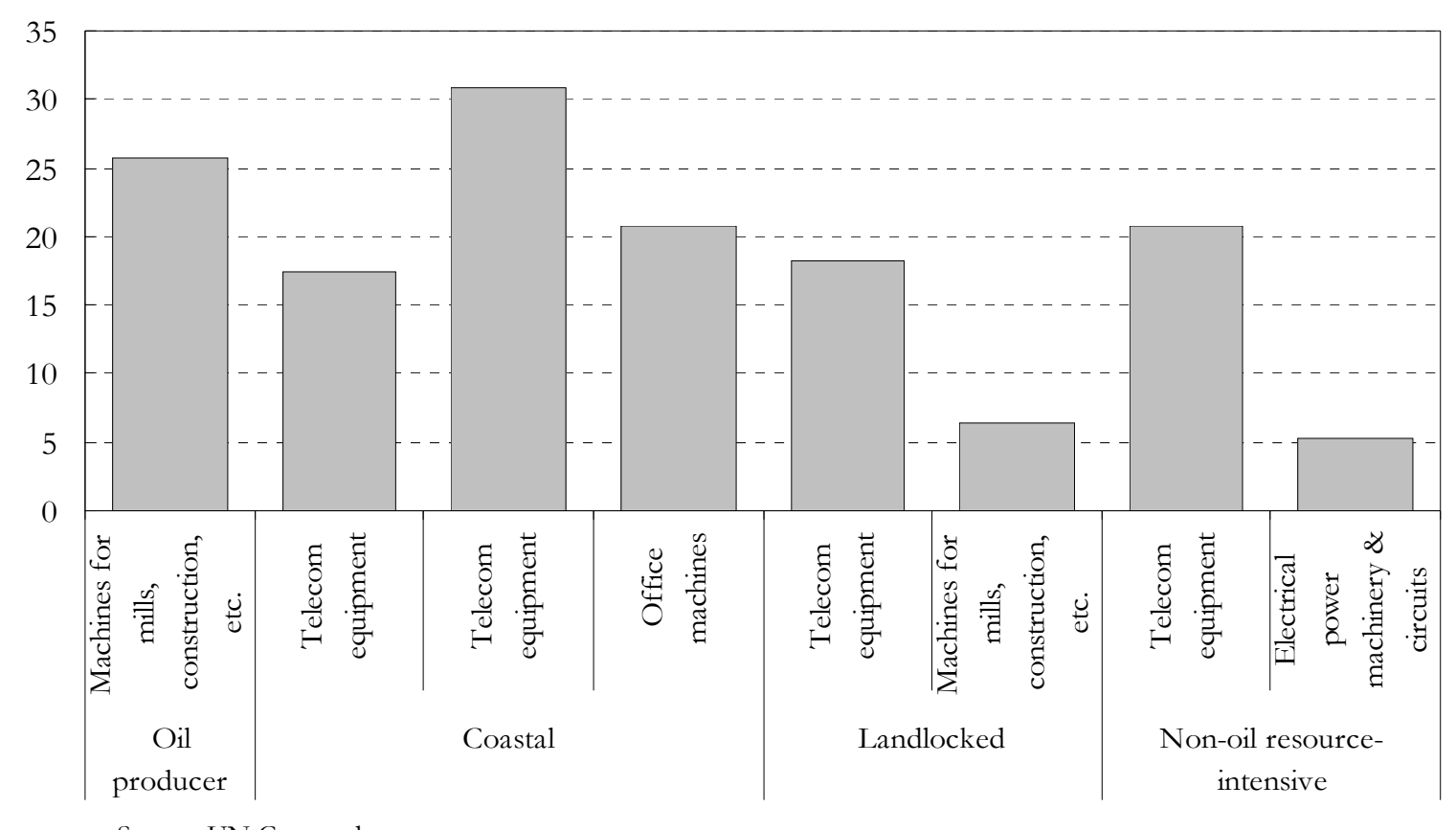

total. Transport equipment (10 percent) and clothing ( 7 percent) are the fastest-growing categories and are the only two not related to processing of resources.

Although Europe is still the dominant destination for manufacturing exports, Asian destinations are becoming more important for oil-producing and coastal countries. Asia is the fastest-growing destination for manufacturing exports of oil-producing countries, which tend to be raw-material-based, such as wood and leather; however, these are a tiny proportion of total exports from oil-producing countries. For coastal countries, the EU-15 is usually the most popular destination in the four main manufacturing categories, although industrial Asia is the dominant destination for nonferrous metals. The manufacturing exports of some landlocked countries also reflect the commodity boom, but the most pronounced development is the surge in exports of clothing. Exports of nonmetallic mineral manufactures dominate for non-oil resource-intensive countries. ${ }^{14}$

\footnotetext{
${ }^{14}$ Industries selected from all manufacturing two-digit categories were those that accounted for at least 10 percent of manufacturing exports and did not experience a large decline between 1990 and 2005. Although clothing exports from landlocked countries have grown strongly since 1990, the high growth rate shown in Table 8 for this category is exaggerated by the fact that Southern African Customs Union (SACU) countries have reported separate country data to Comtrade only since 2000; thus, for example, Lesotho's exports would be included in 2005 but not in 1990. See Appendix 1.
} 


\section{Table 8. Growth of Major Manufacturing Export Categories by Geographic Group, 1990-2005}

(Percent)

\begin{tabular}{|c|c|c|c|}
\hline SITC Code and Industry & Growth Rate & $\begin{array}{c}\text { Share of } \\
\text { Manufacturing } \\
\text { Exports }\end{array}$ & $\begin{array}{l}\text { Main Destinations in } \\
\text { Descending Order }{ }^{1}\end{array}$ \\
\hline \multicolumn{4}{|c|}{ Sub-Saharan Africa } \\
\hline 68 Nonferrous metals & 83.0 & 29.4 & $\begin{array}{l}\text { Industrial Asia, EU-15, } \\
\text { United States }\end{array}$ \\
\hline 66 Nonmetallic mineral manufactures & 352.0 & 27.6 & EU-15, United States, China \\
\hline 73 Transport equipment & 511.6 & 9.8 & $\begin{array}{l}\text { EU-15, Industrial Asia, } \\
\text { United States }\end{array}$ \\
\hline 84 Clothing & 209.5 & 7.2 & $\begin{array}{l}\text { United States, EU-15, } \\
\text { Industrial Asia }\end{array}$ \\
\hline \multicolumn{4}{|c|}{ Oil Exporters } \\
\hline $\begin{array}{l}61 \text { Leather and other animal skin } \\
\text { products }\end{array}$ & 85.7 & 12.4 & $\begin{array}{l}\text { EU-15, Industrial Asia, } \\
\text { China }\end{array}$ \\
\hline 63 Wood and cork manufactures & 98.9 & 20.3 & EU-15, United States, China \\
\hline 68 Nonferrous metals & 32.6 & 11.8 & $\begin{array}{l}\text { EU-15, China, Developing } \\
\text { Asia }\end{array}$ \\
\hline \multicolumn{4}{|c|}{ Coastal } \\
\hline 66 Nonmetallic mineral manufactures & 289.9 & 15.2 & EU-15, United States, China \\
\hline 67 Iron and steel & 351.9 & 18.7 & $\begin{array}{l}\text { EU-15, Industrial Asia, } \\
\text { Developing Asia }\end{array}$ \\
\hline 68 Nonferrous metals & 188.1 & 33.7 & $\begin{array}{l}\text { Industrial Asia, EU-15, } \\
\text { United States }\end{array}$ \\
\hline 73 Transport equipment & 530.5 & 12.9 & $\begin{array}{l}\text { EU-15, Industrial Asia, } \\
\text { United States }\end{array}$ \\
\hline \multicolumn{4}{|c|}{ Landlocked } \\
\hline 66 Nonmetallic mineral manufactures & 104.7 & 37.6 & $\begin{array}{l}\text { EU-15, United States, } \\
\text { Developing Asia }\end{array}$ \\
\hline 67 Iron and steel & 10.2 & 10.4 & $\begin{array}{l}\text { EU-15, Industrial Asia, } \\
\text { United States }\end{array}$ \\
\hline 84 Clothing & $1,424.7$ & 31.5 & $\begin{array}{l}\text { United States, EU-15, } \\
\text { Industrial Asia }\end{array}$ \\
\hline 68 Nonferrous metals & -80.3 & 11.6 & $\begin{array}{l}\text { EU-15, Industrial Asia, } \\
\text { China }\end{array}$ \\
\hline \multicolumn{4}{|c|}{ Non-Oil Resource-Rich } \\
\hline 68 Nonferrous metals & -15.5 & 19.7 & $\begin{array}{l}\text { Industrial Asia, China, } \\
\text { Developing Asia }\end{array}$ \\
\hline 66 Nonmetallic mineral manufactures & $2,145.3$ & 76.9 & $\begin{array}{l}\text { EU-15, United States, } \\
\text { Developing Asia }\end{array}$ \\
\hline
\end{tabular}

Source: UN Comtrade.

${ }^{1}$ Fastest-growing destination of the top three is highlighted in bold.

Note: The selected categories are those two-digit groups accounting for at least 5 percent of total manufacturing exports of the sub-Saharan African aggregate and at least 10 percent for the subgroups in 2005. The destination growth rates on which the final column is based are weighted by the 2005 share of that destination in total exports of that category for the relevant group. SITC = Standard Industrial Trade Classification. 
Table 9. Top Two Markets and Suppliers of Major Manufacturing Exports, 2005

\begin{tabular}{|c|c|c|c|c|c|c|}
\hline Industry & $\begin{array}{c}\text { Value } \\
\text { (millions } \\
\text { of } \\
\text { dollars) } \\
\end{array}$ & $\begin{array}{l}\text { Growth } \\
2000-05 \\
\text { (percent; } \\
\text { annual) }\end{array}$ & Market 1 & Market 2 & Supplier 1 & Supplier 2 \\
\hline $\begin{array}{l}\text { Veneers, plywood boards, and } \\
\text { other wood }\end{array}$ & 791.1 & 21.1 & EU-15 & $\begin{array}{l}\text { Industrial } \\
\text { Asia }\end{array}$ & South Africa & Ghana \\
\hline Pearls and precious stones & $9,174.5$ & 15.4 & EU-15 & $\begin{array}{l}\text { United } \\
\text { States }\end{array}$ & Botswana & $\begin{array}{l}\text { South } \\
\text { Africa }\end{array}$ \\
\hline Crude forms of iron & $3,031.2$ & 22.3 & EU-15 & $\begin{array}{l}\text { Industrial } \\
\text { Asia }\end{array}$ & South Africa & Zimbabwe \\
\hline Iron ingots & 645.3 & 17.6 & EU-15 & $\begin{array}{l}\text { Developing } \\
\text { Asia }\end{array}$ & South Africa & n.a. \\
\hline Sheet iron & 940.9 & 39.0 & EU-15 & China & South Africa & n.a. \\
\hline $\begin{array}{l}\text { Silver and platinum group } \\
\text { metals }\end{array}$ & $5,518.6$ & 7.8 & $\begin{array}{l}\text { Industrial } \\
\text { Asia }\end{array}$ & $\begin{array}{l}\text { United } \\
\text { States }\end{array}$ & South Africa & n.a. \\
\hline Copper & 890.6 & 33.5 & China & $\begin{array}{l}\text { Developing } \\
\text { Asia }\end{array}$ & Zambia & $\begin{array}{l}\text { South } \\
\text { Africa }\end{array}$ \\
\hline Aluminum & $2,632.0$ & 23.4 & EU-15 & $\begin{array}{l}\text { Industrial } \\
\text { Asia }\end{array}$ & Mozambique & $\begin{array}{l}\text { South } \\
\text { Africa }\end{array}$ \\
\hline $\begin{array}{l}\text { Nonelectrical machinery and } \\
\text { appliances }\end{array}$ & $1,542.7$ & & EU-15 & $\begin{array}{l}\text { United } \\
\text { States }\end{array}$ & South Africa & n.a. \\
\hline Road motor vehicles & $2,358.5$ & 23.1 & $\begin{array}{l}\text { Industrial } \\
\text { Asia }\end{array}$ & EU-15 & South Africa & n.a. \\
\hline Clothing, except fur & $2,401.4$ & 7.5 & $\begin{array}{l}\text { United } \\
\text { States }\end{array}$ & EU-15 & Mauritius & Madagascar \\
\hline
\end{tabular}

Source: UN Comtrade.

Note: The industries correspond to three-digit SITC product categories. Where the second supplier is n.a., the first supplier accounts for 100 percent of exports.

South Africa, along with other southern African countries, dominates most manufactured export categories in sub-Saharan Africa (Table 9). Eleven product categories account for 84 percent of all sub-Saharan African manufacturing exports. For seven of these, the EU-15 is the most popular destination, and for seven of them, South Africa is the dominant supplier. The products for which South Africa is not in the top two suppliers reflect resource endowments (diamonds in Botswana, copper in Zambia, and hydroelectricity in Mozambique) and the emergence of a significant textile industry (Mauritius and Madagascar).

The levels of clothing exports reflect the positive impact of AGOA and the mixed impact of the elimination of remaining bilateral quotas on textiles and clothing. The latter occurred under the WTO Agreement on Textiles and Clothing (ATC) at the end of 2005. Although this had a negative effect on some countries, the ATC has not eliminated sub-Saharan Africa's textile 
industry. ${ }^{15}$ Clothing exports are important for Lesotho and Swaziland, as well as Mauritius and Madagascar (see Table 9). Textile exports from lessdeveloped countries under AGOA — which has been extended to 2012 — get duty- and quota-free access to U.S. markets even when third-country fabric is used. ${ }^{16}$ Even for exports to Europe, Asian firms have sought to diversify their production base by locating in Africa, partly because "excessive" penetration of European markets by Asian firms has been a sensitive issue since the ATC quotas expired. Madagascar's textile industry has performed well after the expiration of the Multi-Fiber Arrangement by graduating to higher-value-added textile exports to Europe. Mauritius has had similar success and records the highest value-added among sub-Saharan African textile exporters to the United States. ${ }^{17}$

\footnotetext{
${ }^{15}$ The ATC was the transitional agreement for phasing out the Multi-Fiber Arrangement.

${ }^{16}$ Mattoo, Roy, and Subramanian (2003) show that AGOA undercuts some of its more liberal provisions with restrictions in its product coverage and application of quotas to the total amount of U.S. textile imports that can receive relief.

${ }^{17}$ This is based on the ratio of the value share to the volume share of textile exports from sub-Saharan African countries to the United States.
} 


\title{
Benchmarking Sub-Saharan African Trade Performance
}

\begin{abstract}
Many studies have investigated whether regions or countries undertrade or overtrade relative to a benchmark model of trade flows. ${ }^{18}$ Gravity models are commonly used for setting this benchmark; they derive the level of bilateral trade (exports and imports) from natural determinants: in its simplest specification, trade between any two countries is expected to be directly related to their economic size (GDP) and level of development (GDP per capita) and inversely related to the distance between them. When the observed level of trade exceeds the model's prediction, the country pair is considered to overtrade; when it falls below the prediction, they are said to undertrade.
\end{abstract}

Undertrading is influenced by all barriers to trade, including structural and policy-induced impediments. The difference between actual and predicted trade - the residual — is the unexplained portion of bilateral trade flows. The estimation includes as many of the natural determinants of trade flows as possible. In addition to the core variables of size and distance, they include geographic characteristics (for example, landlocked versus coastal), participation in customs or currency unions, and historic linkages between trading partners. The residual then captures the impact of trade policy and such impediments to trade as infrastructure, trade facilitation, and business climate. Overtrading probably reflects structural aspects not captured by the gravity model, such as the emergence of intra-industry trade (see below). An alternative approach is to include additional determinants of trade in the gravity model. For example, Broadman (2007) adds indicators for export and import customs procedures, port quality, domestic business procedures, and quality of utilities to the base gravity model specification. Some variables, such as the number of customs and business procedures, are found to have a substantial negative impact on sub-Saharan African trade; these would represent components of undertrading if they were not included in the model. However, it is difficult to assign precise influence to specific sets of included variables, because they could be correlated with other omitted variables that also have an impact on trade flows. The remainder of this study therefore adopts the more parsimonious gravity model specification.

${ }^{18} \mathrm{IMF}$ (2002, Chapter III) provides extensive discussion and references. 
Benchmarking trade using the gravity model has limitations. First, the model is not a comprehensive economic model of trade flows. It has no role for factor proportions, comparative advantage, exchange rates, or other determinants of patterns suggested by international trade theory. Second, gravity models can be highly unstable in predicting the influence of variables like distance and degree of development. Because these are part of any economy's structure, the instability of their coefficients suggests that the gravity model is affected by variables beyond those at the model's core. Finally, because gravity models use data on merchandise trade, they do not take into account trade in services, which has been growing recently. Nevertheless, its parsimonious specification and extensive track record of applications have established the gravity model as an accepted tool for analyzing trade flows.

\section{Estimation Results}

An IMF study of global trade in the late 1990s found modest overtrading for sub-Saharan Africa (IMF, 2002). ${ }^{19}$ It estimated a gravity model for bilateral flows from 1995 through 1999. East Asia overtraded by more than 40 percent relative to the model's prediction and sub-Saharan Africa by about 5 percent. In contrast, developing countries in the Western Hemisphere undertraded by about 10 percent and in South Asia and the Middle East and North Africa (MENA) by about 40 percent. Moreover, sub-Saharan Africa's overtrading may have been a modest 5 percent globally, but it was 50 percent when both partners were in sub-Saharan Africa.

A gravity model was estimated covering the period of the recent African trade boom. The specifications and data for estimating the model are an extension of those in Rose (2002). He estimates a global gravity model for 178 countries using data spanning 1948-99. The data set has more than 12,000 country pairs and contains a full range of right-hand-side variables, including real GDP, GDP per capita, distance, land area, geographic and relevant colonial characteristics, and presence in a currency union. For new estimates, the macroeconomic variables were updated to 2005 from the IMF Direction of Trade Statistics and World Economic Outlook databases, deflated to 2000 U.S. dollars. ${ }^{20}$ Because the regression technique is ordinary least squares, it does not make any adjustment for possible endogeneity of explanatory variables.

\footnotetext{
${ }^{19}$ The estimation is built on a background study by Rose (2002).

${ }^{20}$ Rose deflates Direction of Trade Statistics data to constant 1982-84 dollars, and his GDP data were taken from World Development Indicators 2000 or the Penn World Tables version 5.6 (Heston and others, 1995) when the former were missing. Baldwin and Taglioni (2006) emphasize that the impact of an inappropriate deflator is magnified in long-horizon regressions.
} 
The new estimates cover relatively short periods. Using longer periods in a single sample runs a variety of risks, including subsample instability and divergent trends across different countries (Baldwin and Taglioni, 2006). Four regressions were estimated. First, as a check that the method could reproduce existing estimates, Rose's estimates were replicated on a subset of his data covering 1990-99, but using the new GDP data to take into account revisions and updated deflators. ${ }^{21}$ Second, an equation identical to the first regression was estimated with data for 2000-05; this is the main regression used in the benchmarking calculations. Two additional equations were estimated as robustness checks, one allowing for selectivity in bilateral pairs that report zero trade and one allowing for random effects across trading pairs. All regressions contain dummies for year to control for influences on trade common to all countries in each year (for example, global business cycle effects). The regressions also control for geographic characteristics, including whether either trade partner had resource-intensive exports or was landlocked and whether a pair has a common border. Residuals can then be averaged across groups; for example, in terms of coastal, landlocked, and resource-intensive for sub-Saharan African countries. Thus the residuals will indicate whether, relative to the global prediction for the impact of the included characteristics, sub-Saharan African countries tend to trade more or less than the model predicts.

The estimates are relatively stable but there are notable cases of individual parameter instability. Table 10 reports the coefficients on some key variables from the regressions for 2000-05 (columns B, C, and D) along with a Rosetype regression covering 1990-99 for comparison purposes (column A). Although the coefficients on distance, GDP per capita, presence of regional trade agreements (RTAs), and the geographic variables are broadly similar, the coefficients on GDP and currency union fall substantially, whereas that on common border rises. The currency union variable is estimated to be negative in the $\mathrm{B}, \mathrm{C}$, and $\mathrm{D}$ regressions, although the effect is not significant. ${ }^{22}$ Of particular interest is the shifting relative influence of GDP and GDP per capita; the impact of the latter on trade increases relative to the former in more recent regressions. ${ }^{23}$ Thus, other things being equal, the

\footnotetext{
${ }^{21}$ The dependent variable for the new regressions was calculated slightly differently from Rose (2002). As recommended by Baldwin and Taglioni (2006), it is calculated as the average of log exports plus log imports, rather than the log of the average of exports and imports. Calculations not reported confirm that this change alone makes little difference to the results.

${ }^{22}$ Tsangarides, Ewenczyk, and Hulej (2006) find a currency union effect much closer to the sizable positive effect found by Rose (2002), although they do not report estimates for later subperiods in their sample (19482002). Because of indications that large valuation effects induced by euro-dollar volatility affect the post-2000 sample, the regressions include an interaction of country and year effects for euro-linked countries, including those in the CFA zone.
}

${ }^{23}$ IMF (2002) reported an even smaller coefficient, 0.27, on GDP per capita than that found by Rose (2002). 
Table 10. Coefficients on Selected Variables from the Global Gravity Model (Dependent variable as average of log trade flows)

\begin{tabular}{|c|c|c|c|c|}
\hline & $\begin{array}{c}\text { A } \\
1990-99 \\
\end{array}$ & $\begin{array}{c}\text { B } \\
2000-05 \\
\end{array}$ & $\begin{array}{c}C \\
2000-05 \\
\end{array}$ & $\begin{array}{c}\mathrm{D} \\
2000-05 \\
\end{array}$ \\
\hline $\begin{array}{l}\text { Distance } \\
(\log )\end{array}$ & $\begin{array}{l}-0.93 \\
(0.03)^{* *}\end{array}$ & $\begin{array}{l}-1.03 \\
(0.03)^{* *}\end{array}$ & $\begin{array}{l}-1.06 \\
(0.02)^{* *}\end{array}$ & $\begin{array}{l}-1.03 \\
(0.03)^{* *}\end{array}$ \\
\hline $\begin{array}{l}\text { Pair GDP } \\
\text { (log product) }\end{array}$ & $\begin{array}{l}0.51 \\
(0.01)^{* *}\end{array}$ & $\begin{array}{l}0.39 \\
(0.01)^{* *}\end{array}$ & $\begin{array}{l}0.4 \\
(0.01)^{* *}\end{array}$ & $\begin{array}{l}0.24 \\
(0.01)^{* *}\end{array}$ \\
\hline $\begin{array}{l}\text { Pair GDP per capita } \\
\text { (log product) }\end{array}$ & $\begin{array}{l}0.47 \\
(0.02)^{* *}\end{array}$ & $\begin{array}{l}0.42 \\
(0.02)^{* *}\end{array}$ & $\begin{array}{l}0.44 \\
(0.01)^{* *}\end{array}$ & $\begin{array}{l}0.39 \\
(0.01)^{* *}\end{array}$ \\
\hline Currency union & $\begin{array}{c}0.61 \\
(0.21)^{* *}\end{array}$ & $\begin{array}{l}-0.2 \\
(0.20)\end{array}$ & $\begin{array}{c}-0.16 \\
(0.09)^{*}\end{array}$ & $\begin{array}{c}-0.28 \\
(0.20)\end{array}$ \\
\hline Regional trade agreement & $\begin{array}{l}0.34 \\
(0.02)^{* *}\end{array}$ & $\begin{array}{l}0.35 \\
(0.04)^{* *}\end{array}$ & $\begin{array}{l}0.36 \\
(0.03)^{* *}\end{array}$ & $\begin{array}{l}0.37 \\
(0.07)^{* *}\end{array}$ \\
\hline $\begin{array}{l}\text { Land area } \\
\text { (log product) }\end{array}$ & $\begin{array}{l}0.15 \\
(0.01)^{* *}\end{array}$ & $\begin{array}{l}0.27 \\
(0.01)^{* *}\end{array}$ & $\begin{array}{l}0.28 \\
(0.01)^{* *}\end{array}$ & $\begin{array}{l}0.33 \\
(0.01)^{* *}\end{array}$ \\
\hline Landlocked & $\begin{array}{l}-0.94 \\
(0.04)^{* *}\end{array}$ & $\begin{array}{l}-0.85 \\
(0.10)^{* *}\end{array}$ & $\begin{array}{l}-0.87 \\
(0.02)^{* *}\end{array}$ & $\begin{array}{l}-1.00 \\
(0.05)^{* *}\end{array}$ \\
\hline Common border & $\begin{array}{l}1.13 \\
(0.14)^{* *}\end{array}$ & $\begin{array}{l}1.29 \\
(0.14)^{* *}\end{array}$ & $\begin{array}{l}1.3 \\
(0.07)^{* *}\end{array}$ & $\begin{array}{l}1.38 \\
(0.16)^{* *}\end{array}$ \\
\hline Colonial link & $\begin{array}{l}1.19 \\
(0.11)^{* *}\end{array}$ & $\begin{array}{l}1.22 \\
(0.15)^{* *}\end{array}$ & $\begin{array}{l}1.21 \\
(0.09)^{* *}\end{array}$ & $\begin{array}{l}1.48 \\
(0.23)^{* *}\end{array}$ \\
\hline $\begin{array}{l}\text { R-squared } \\
\text { Observations (pairs) }\end{array}$ & $\begin{array}{c}0.66 \\
52,904(8,528)\end{array}$ & $\begin{array}{c}0.65 \\
31,486(6,168)\end{array}$ & $\begin{array}{c}\cdots \\
47,214\end{array}$ & $\begin{array}{c}0.63 \\
31,486(6,168)\end{array}$ \\
\hline
\end{tabular}

Sources: Rose (2002); and IMF staff calculations.

Note: Standard errors robust to clustering by pairs are in parentheses, with significance indicated at $1(* *)$ percent.

Regression A replicates the regression from Rose (2002) on a subsample of Rose's data, but with updated GDP data; it is presented for purposes of comparison. The main regression is $\mathrm{B}$, which forms the basis of the trade benchmarking calculations. Column $\mathrm{C}$ reports a Heckman two-step estimator of the same model as in $\mathrm{B}$, with a selection equation for observations that have zero bilateral trade. Column $\mathrm{D}$ reports a panel regression of the gravity model that allows for random effects across bilateral pairs. All regressions also include dummies for year, and the last three regressions have dummies for countries whose exports are dominated by fuel or nonfuel primary exports. 
Table 11. Undertrading in Developing Countries, 2000-05 (Average difference between actual and predicted trade, in logarithms)

\begin{tabular}{lrc}
\hline & \multicolumn{2}{c}{ Trade Partners } \\
\cline { 2 - 3 } Region & All & Intraregional \\
\hline Sub-Saharan Africa & -0.21 & -0.04 \\
South Asia & 0.14 & 0.12 \\
East Asia & 0.82 & 1.68 \\
Latin America and Caribbean & -0.03 & 0.43 \\
Middle East and North Africa & -0.40 & 0.04 \\
& & \\
High-income countries & -0.06 & 0.12 \\
EU-15 & 0.02 & 0.12 \\
\hline
\end{tabular}

Source: IMF staff estimates.

Note: Based on a gravity equation estimated on annual data. A negative number indicates a negative residual and thus undertrading; similarly, a positive number indicates overtrading.

combined economic size of a trading pair has a smaller impact over time on bilateral trade relative to their combined per capita income. This aspect of the estimates is discussed further below.

New estimates for 2000-05 find substantial changes in regional patterns of undertrading or overtrading (Table 11). ${ }^{24}$ These numbers are based on the residuals from the $\mathrm{B}$ regression in Table 10 . They not only confirm the conclusion of IMF (2002) and others that East Asia is a large overtrader; they also show that the extent of overtrading has almost doubled since the 2002 study. Sub-Saharan Africa switches on average from modest overtrading to undertrading by more than 20 percent. In intraregional trade, sub-Saharan Africa's performance has improved but is now just at the predicted level.

The results confirm the continuation of trends identified earlier. IMF (2002) supplemented the analysis of 1995-99 by benchmarking trade performance for five-year subperiods for 1980 through 1999. This demonstrated that subSaharan Africa's tendency to overtrade was declining sharply, from nearly 30 percent in 1980-84 to just 5 percent in 1995-99. East Asia's overtrading declined in the 1980s to 19 percent before increasing again, and South Asia's undertrading was diminishing. Coe and Hoffmaister (1999) also found that the degree of sub-Saharan Africa's overtrading was falling over time.

Although consistent with these trends, the results may also indicate that the basic gravity model does not fully capture the impact of transport costs on

${ }^{24}$ The regression is based on logarithms of trade and GDP. Thus multiplication by 100 approximates the percentage difference between actual and predicted trade. 
African trade; note that sub-Saharan Africa, along with MENA, is also unusual in terms of its low level of intraregional trade relative to the benchmark. Limão and Venables (2001) find that including direct measures of transport costs in the gravity model absorbs much of the estimated underperformance of intraregional and external trade for sub-Saharan African countries.

The new results are partly attributable to the stronger role of the level of development in explaining trade patterns than previously assigned by the gravity model. The new estimates find a smaller role for GDP and a larger role for GDP per capita than in IMF (2002). As the 2002 study explains, global trade patterns are increasingly driven by the fact that demand for product variety rises with economic growth, and specialization is the most efficient cost structure. Thus consumers in rich countries demand an everwider variety of products, which are produced by vertically integrated structures spread across many countries. This link between product demand patterns and trade probably lies behind the rising influence of per capita incomes in the model. The systematic differences by region indicate that regions are differently placed in their ability to take advantage of this kind of trade. However, for trade within sub-Saharan Africa, the variation in level of development is not as dominant because most countries are lower income, so trade values come much closer to the model's prediction.

Landlocked countries within sub-Saharan Africa have been rising to the benchmark in the past two or three years. However, coastal and resourceintensive groups have remained large undertraders since 2000. Figure 8 breaks down the deviations of observed from predicted trade for each geographic group by year. The performance of landlocked countries trended upward, moving from undertrading consonant with the other groups in 2000 to overtrading by nearly 10 percent in 2004 and $2005 .{ }^{25}$ No change is evident for the other groups, for which year-by-year gaps hew to the average. The shortfall shows no sign of having narrowed during the commodity export boom, suggesting that much of the growth in trade can be explained by global factors and predetermined country characteristics (for example, whether the country exports fuel).

The sub-Saharan African groups on average overtrade with East and South Asia and undertrade with Latin America and the Caribbean (LAC) and MENA. Table 12 breaks down the gravity model residuals by sub-Saharan

\footnotetext{
${ }^{25}$ This of course does not mean that landlocked countries were outperforming coastal countries, which still have their advantage of better access to global markets. It means that taking account of the poorer access of landlocked countries, their trade performance was relatively good in the later years of the sample.
} 
Figure 8. Sub-Saharan Africa: Undertrading by Geographic

Subgroup, 2000-05

(Average difference between actual and predicted trade, in logarithms multiplied by 100 )

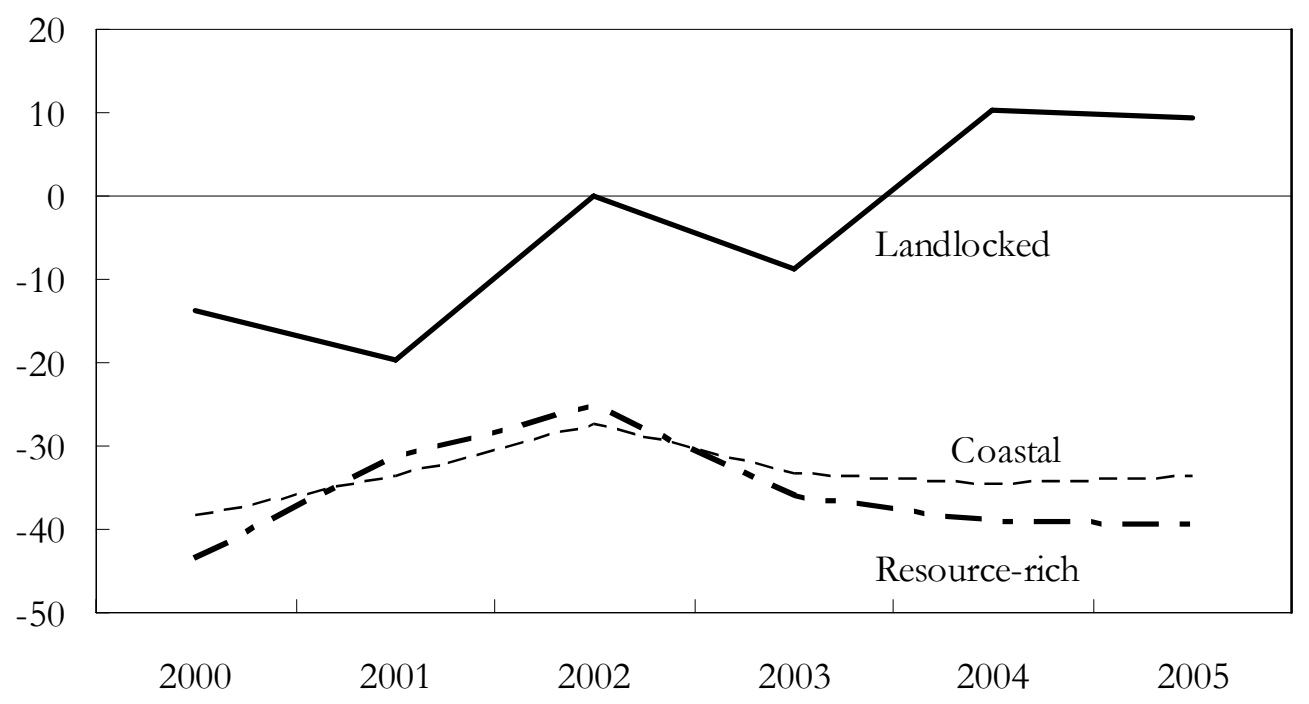

Source: IMF staff estimates.

Note. Based on a gravity equation estimated on annual data. Regression residuals were multiplied by 100 to express the results as approximate percentage deviations. The interpretation of the signs remains as in Table 8.

Table 12. Undertrading in Sub-Saharan Africa, 2000-05 (Average difference between actual and predicted trade, in logarithms)

\begin{tabular}{lccc}
\hline & \multicolumn{3}{c}{ Trade Partners } \\
\cline { 2 - 4 } Region & Coastal & Landlocked & $\begin{array}{c}\text { Resource- } \\
\text { intensive }\end{array}$ \\
\hline South Asia & 0.66 & 0.42 & 0.14 \\
East Asia & 0.68 & 0.64 & 0.85 \\
Latin America and Caribbean & -1.20 & -0.98 & -0.44 \\
Middle East and North Africa & -1.07 & -0.78 & -1.32 \\
EU-15 & -0.14 & -0.07 & -0.08 \\
China & 1.26 & 1.29 & 1.60 \\
United States & -0.65 & -0.15 & 0.62 \\
High-income countries & -0.38 & -0.25 & -0.46 \\
\hline
\end{tabular}

Source: IMF staff estimates.

Note: See Table 8. 
African subgroup and non-sub-Saharan African region. The results reflect the earlier analysis in that the regions with general overtrading-South and East Asia-tend to overtrade with sub-Saharan African subregions as well; the converse is true for undertrading. Not surprisingly, because the two groups have similar endowments, resource-intensive sub-Saharan African countries have significant undertrading with MENA. Significant overtrading between coastal countries and South Asia may partially reflect the presence of ethnic Indian communities in several eastern and southern sub-Saharan African countries.

At the subregional or country level, the sub-Saharan African subgroups have modest undertrading with the EU-15, large overtrading with China, and, except for resource-rich countries, undertrading with the United States. Because the calculations in Table 12 reflect characteristics of a trading pair, they cannot be exclusively interpreted in terms of the sub-Saharan African trading partner. ${ }^{26}$ For example, sub-Saharan Africa's large overtrading with China is a reflection of China's high participation in global trade, although the calculation does plausibly indicate that overtrading is highest with the resource-intensive group. The results for the United States again point to resource-driven trade, although the big difference between calculated undertrading for coastal versus landlocked countries likely reflects the relative success of AGOA in promoting exports from landlocked countries. Trade is quite close to the gravity benchmark for all groups with the EU-15 countries, although the magnitude of the shortfall is largest for coastal countrieswhich again indicates their lack of participation in global trade despite relatively favorable circumstances.

The boom in sub-Saharan African trade has done little to offset the region's lack of integration into global trade. Relative to the global pattern, the sharp increase in exports from resource-intensive sub-Saharan African countries has not closed their shortfall in trade compared with countries with similar characteristics in other regions. Similarly, coastal sub-Saharan African countries, the model implies, have not been able to exploit their advantages of lower transportation costs and shorter distance to global markets.

\section{Alternative Estimation Methods}

Alternative methods have been proposed for checking the robustness of the findings from the basic gravity model. A key concern with the estimation of

\footnotetext{
${ }^{26}$ The calculations of overtrading or undertrading are based on estimated residuals from a regression, and thus are subject to statistical uncertainty. This uncertainty grows progressively larger as the sample size over which the group averages are calculated gets smaller. Standard error bands around the individual country rows in Table 12 would be relatively large.
} 
the model is the treatment of trading pairs where zero trade flows are reported. These observations are discarded by default in a gravity model because it is expressed in logarithms, and thus a trade value of zero cannot be calculated. Researchers have recommended various procedures for dealing with this problem. One common approach is to add a small positive constant to each zero trade flow so that the logarithm can be evaluated, and then use a Tobit method to account for the bunching of values around this new cutoff value. ${ }^{27}$ However, other studies question whether the Tobit method is consistent with the underlying interpretation of the gravity model (Linders and de Groot, 2006). They argue that using the Tobit implies that in some cases trade would be negative if it could be observed. ${ }^{28}$ Alternatively, zero reported trade may represent mismeasurement of actual flows, in which case incorporating them in the estimation runs the risk of bias due to measurement error. One compromise among these various considerations is to use a Heckman model, because it estimates a separate selection equation for the zero-valued (or missing) trade data while leaving open the precise interpretation of why trade is not always observed. The number of such values is substantial: the sample size increases from 31,500 in the leastsquares regression to 47,200 when the Heckman method is used. A second alternative allows additional controls for country-pair effects; this is implemented through a random effects panel regression. ${ }^{29}$

Alternative estimation methods confirm that the gravity model parameters are fairly robust. The Heckman estimates are reported in column $\mathrm{C}$ of Table 10 and the random effects estimates in column $\mathrm{D}$. The main challenge in implementing the Heckman method is the need to specify instruments for the selection equation; that is, variables that explain the probability of positive trade flows while being weakly correlated with the level of trade. These are difficult to find because in principle the gravity model itself should encompass all determinants of trade flows. The chosen instruments are the levels of GDP per capita for each trade partner. These variables enter the gravity equation only as a product; arguably, they have a separate role in specifying a minimal level of development for trade to occur, or to be

\footnotetext{
${ }^{27}$ This is one of the many robustness checks implemented by Rose (2004). Tsangarides, Ewenczyk, and Hulej (2006) discuss the role of the treatment of zeroes and endogeneity of the currency union variable in estimating the impact on trade of currency unions. Estimates that use observations of zero bilateral trade (which the basic gravity model cannot do because it takes logs) deliver broadly similar implications for the impact of currency unions on trade as the least-squares estimates.

${ }^{28}$ The Tobit estimator deals with data on a dependent variable where it is known that a set of values above or below a certain threshold was reported as being at that threshold; for example, a survey that recorded only whether incomes were at least at a certain level. However, a Tobit model with a cutoff at zero (or its replacement value after taking logs) could be interpreted as modeling a range of potential trade values that are not large enough to overcome fixed costs of exporting.

${ }^{29}$ Country-pair fixed effects, as opposed to random effects, are collinear with variables already in the regression that do not vary over time for a country pair (for example, the geographic variables).
} 
properly recorded. The resulting gravity coefficient estimates are very close to the earlier specification. ${ }^{30}$ The currency union variable is again negative and is now borderline significant. The Heckman method sheds some light on why this is the case. In the underlying selection equation, which predicts the probability that positive trade flows will be observed, the currency union variable has a strong positive effect. Thus one aspect of being in a currency union is that it makes measured trade more likely, which may reflect the superior data quality when trade flows are being monitored by a regional institution. Conventional least-squares estimates of the currency union effect may therefore compound measurement of trade with the true impact of a common currency, imparting some instability to the parameter as the sample changes. The main difference between the random effects method and the others is the somewhat lower weight it attaches to GDP and the higher weight to a colonial link between countries.

The estimates of undertrading using alternative techniques are also similar to those reported earlier. This is not surprising given the stability of the parameter estimates. The Heckman estimates find undertrading for subSaharan Africa of 10.3 percent, compared with 20 percent in Table 11. For East Asia overtrading is now 91 percent, and for South Asia 22 percent. MENA undertrading is 32 percent, whereas the Latin American countries, which had undertraded according to the earlier estimate, now have modest overtrading of 7 percent. The Heckman method also finds that for intraregional trade, sub-Saharan Africa overtrades by 10 percent; this was calculated as slight undertrading using the least-squares method. On balance, therefore, though including zero-valued trade flows does not lead to big changes in magnitude relative to the benchmark, it does produce a slightly improved assessment of sub-Saharan African trade performance. The random effects estimate of global sub-Saharan African undertrading is smaller-about 7 percent-but the direction of the effects is very close to that found by the other estimates. It is likely that the random effects absorb some of the estimated undertrading from the other models into the country effects, thus reducing the gap between actual and predicted trade that needs to be explained.

\footnotetext{
${ }^{30}$ Although it is conceptually useful to think of the Heckman method as a two-step approach, the reported estimates come from maximum likelihood estimation of the two equations jointly. The standard likelihood ratio test that the correlation between the error in the selection equation and the regression equation is zero is rejected, indicating that the Heckman method is warranted.
} 


\section{CHAPTER}

\section{Making Trade an Engine of Development}

Evidence indicates that sub-Saharan Africa is performing below its export potential. Its export growth derives both from fuels and manufactures, but manufactures are confined to a few resource-based products and are concentrated in southern Africa. Whereas the trade of landlocked countries measures relatively well against the benchmark, that of coastal and resourceintensive countries falls short. Outside of fuels and manufactures, most subSaharan African countries remain dependent on primary exports whose value has grown very sluggishly.

\section{Evolution of Trade Patterns and Income Growth: Experiences Outside Africa}

Experiences in other parts of the world demonstrate a variety of trade pattern trajectories with income growth. Six economies whose resource endowments early in their development resembled those of sub-Saharan African countries were chosen to indicate how sub-Saharan Africa's trade patterns might evolve. Argentina and New Zealand have large agricultural sectors; Chile has a dominant extractive industry; and Thailand, China, and Indonesia participated in the East Asian manufacturing trade boom and thus may offer guidance on how sub-Saharan Africa could make the transition to labor-intensive manufacturing. ${ }^{31}$ Figure 9 presents some key aspects of evolving trade patterns from 1985 to 2005 for these countries, with a more detailed breakdown in Appendix Figure A1.

Increasing per capita income does not necessarily require a transition to predominantly manufacturing-based exports. None of the three non-Asian

\footnotetext{
${ }^{31}$ The latter three countries, along with Chile, are included in the list of sustained growers identified by Johnson, Ostry, and Subramanian (2007); that is, countries that around 1960 had income and institutional quality levels similar to sub-Saharan Africa today, and therefore that might be indicative of growth prospects for sub-Saharan Africa.
} 
Figure 9. Selected Economies: Major Product Category Shares of Total Exports

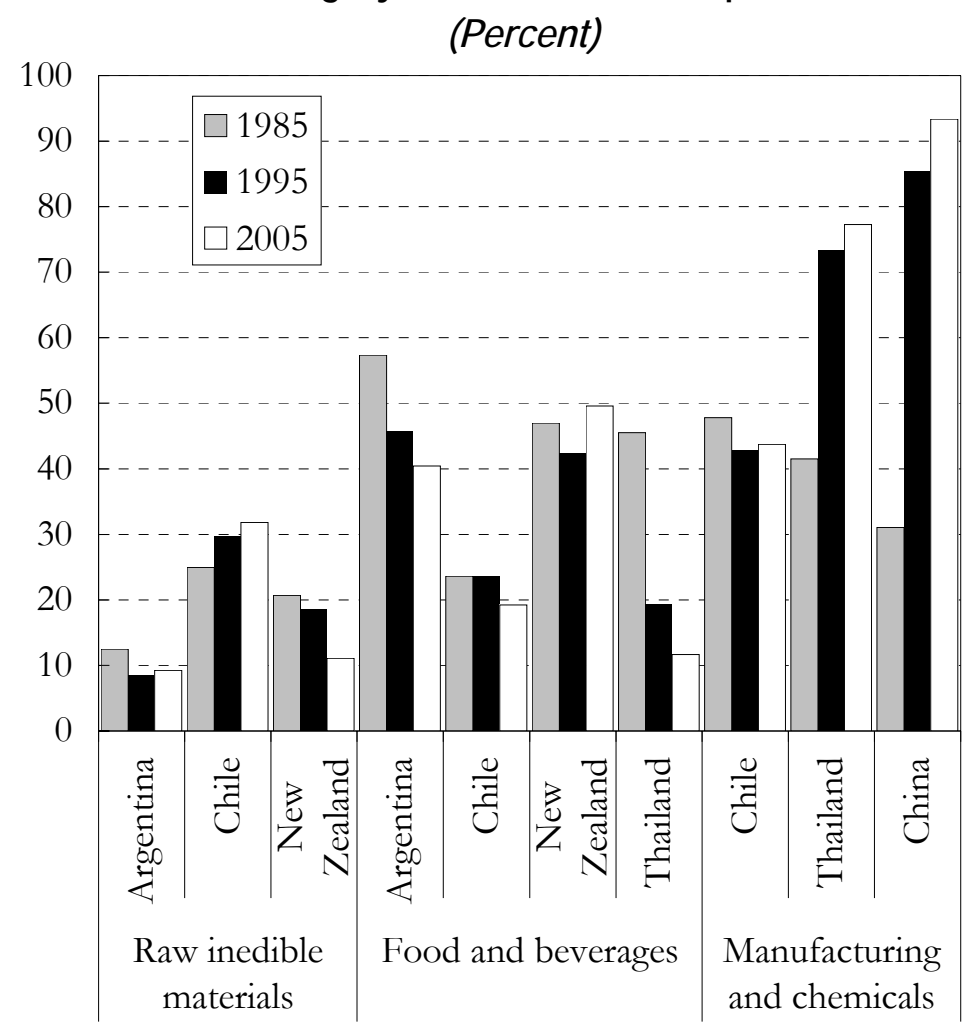

Source: UN Comtrade.

countries has seen a manufacturing export surge. Although the manufacturing share is higher in Chile than in Argentina or New Zealand, this is partly because the copper sector is included in manufacturing. In Argentina and New Zealand, where agriculture is still important, manufacturing accounts for about one-third of exports, up just modestly since 1985. Nevertheless, as Johnson, Ostry, and Subramanian (2007) emphasize, growth in manufactured exports is characteristic of rapid growers in East Asia. This may reflect complex linkages among institutional development, the export pattern, and pro-growth policies; in particular, how the export pattern affects growth will depend on the quality of institutions, which itself changes as the economy grows.

Natural resource-based exports are significant in several middle- and higherincome countries. Agriculture can be a major component of exports even in those economies. In 2005, food and beverages were still 40 percent of total exports for Argentina, 50 percent for New Zealand, and 20 percent for Chile (Figure 9). Chile is unusual among the six in that the export share of raw 
materials has increased since 1985 from one-fourth to nearly one-third of total exports. Though the share has declined in other countries, it is still about 10 percent in Argentina and New Zealand.

In East Asian countries manufacturing has come to dominate exports. In 1985, food and beverages accounted for nearly half of exports from Thailand, and fuels accounted for a third of exports from China and nearly 70 percent from Indonesia (Appendix Figure A1, panel d). The manufacturing share of exports from East Asia has since grown extremely rapidly; it nearly doubled in Thailand and tripled in Indonesia and China. By 2005 it had in fact reached nearly 90 percent of China's total exports.

The success of East Asia is attributable to facilitating the accumulation of capital and skills, reducing trade protection, and reducing transport costs (Martin, 2005; and Rodrik, 1994). Improvements in the education system can facilitate the accumulation of skills, but skills are productive only when complemented by capital. Foreign direct investment has helped, but a domestic pool of savings and an effective financial sector are also important for fostering private investment. Trade liberalization promotes manufacturing exports not least because modern manufacturing networks often involve simultaneous importing and exporting of related products (Jones, 2000).

\section{Constraints on Manufacturing in Sub-Saharan Africa}

The inability to take advantage of economies of scale and poor infrastructure are common constraints to expanding trade. Sub-Saharan African markets are often characterized either by a relatively large number of small, high-cost, localized firms or by just a few firms that have significant domestic market power and little pressure to become more efficient. Local firms are also hampered by such well-documented indirect costs as poor quality of electricity and telecommunication, limited access to financing, and poor governance. Data underlying the World Bank Investment Climate Assessments indicate that such indirect costs account for more than 20 percent of total costs in Mozambique, Zambia, Eritrea, Tanzania, Kenya, and Ethiopia compared with less than 10 percent of total costs in China, Nicaragua, and Bangladesh (Eifert, Gelb, and Ramachandran, 2005). Because tackling these constraints all at once is difficult, countries have sometimes established export processing zones; however, these cannot be protected from a poor business climate and they can become magnets for rent seeking.

External impediments to trade are important but difficult to quantify. Among them are the costs of searching for and verifying business opportunities, setting up marketing channels, and creating access to communications and 
logistics systems for receiving and delivering orders. Informal means of relieving these, such as the use of ethnic networks and personal contacts, have been significant for Indian firms in sub-Saharan Africa; Chinese firms have tended to rely more on government-to-government links or targeted investments in the natural resource sector. ${ }^{32}$ Finally, poor transport infrastructure and multiple border crossings and administrative checkpoints are a major impediment to trade. For example, an Indian firm operating in Ghana found that the transportation cost per container from Accra to Lagos $(\$ 1,000)$ was so high that it was better to invest directly in Nigeria than to export to it (Broadman, 2007).

Integration into global production networks could help boost sub-Saharan Africa's nonprimary exports. Global trade patterns reflect the growing importance of intra-industry trade because production can be more dispersed than in the past (World Bank, 2004; and Broadman, 2007). Intra-industry trade networks can be classified into two types: producer-driven (directed from upstream) and buyer-driven (directed from downstream). Buyer-driven networks may be better suited for sub-Saharan Africa because they require less vertical integration, are less capital-intensive, and are often interested in areas where sub-Saharan Africa already has some capacity, such as tourism, horticulture, and the production of clothing, food, and furniture. Yet in subSaharan Africa the process of integration into production networks tends to be led by foreign, not domestic, firms. For the most part, the constraints on integration into global production networks are the same as the constraints on business development generally.

Attempts to build the textile industry in sub-Saharan Africa have revealed structural constraints that often offset the comparative advantage. As a cotton producer, sub-Saharan Africa has the potential to move up the value chain in textile production. The global trade regime provided incentives to the industry through AGOA and the decisions of Asian producers to relocate production to sub-Saharan Africa to circumvent industrial country quotas. Yet the textile industry in sub-Saharan Africa continues to struggle with high production costs (transport, electricity, and so forth), the limited supply and higher cost of domestically produced yarn, and restrictive rules of origin in trade. Even when use of cheaper Asian yarn was allowed, as under AGOA, the example of Lesotho reveals an industry with an extremely fragile cost base that is vulnerable to exchange rate appreciation.

Coastal countries are the best placed to participate in the global manufacturing export boom, but except for South Africa they have made

\footnotetext{
${ }^{32}$ Access to ethnic networks may explain why firms controlled by minority entrepreneurs tend to outperform
} those controlled by majority entrepreneurs in eastern and southern Africa (Ramachandran and Shah, 1999). 
little progress. ${ }^{33}$ The manufacturing that does take place is often linked to resources and cannot be viewed as emerging intra-industry trade, though it is not surprising that sub-Saharan Africa's manufacturing base is linked to its comparative advantage in resources. Landlocked countries depend on agriculture and raw materials exports; transportation to ports is a significant burden on the development of manufacturing. And although resourceintensive countries have been the strongest beneficiaries of the global commodity boom, the result has been less product diversification in these countries even as regional diversification of their trade has grown.

The current orientation of the global trade regime facing sub-Saharan Africa limits the ability of the region as a whole to benefit from preferential trade arrangements. The tendency toward regionalism in global trade has led to hub-and-spoke trading patterns in which sub-Saharan African countries are at best one spoke for a large global trade partner (Yang and Gupta, 2005). The key preferential trade arrangements, AGOA and EBA, limit their full benefits to sub-Saharan Africa's least developed countries (Box 2). Although these countries in principle thus face no export restrictions to the United States and European Union, they also have the least capacity to build significant manufacturing capability. The restrictive rules of content in the trade arrangements (except for the AGOA textile provisions) make it difficult for a beneficiary country to partner with a low-cost provider of inputs (likely to be an Asian country) that has more manufacturing capacity but is not eligible for AGOA or EBA. This makes sub-Saharan African countries less attractive as, for example, an assembly base for supply chains that include countries ineligible for trade preferences; such operations would face a more unfavorable trade regime (for example, tariff escalation and tariff-rate quotas) that impedes the growth of their manufacturing and processing sectors. ${ }^{34}$ As agricultural exporters, however, sub-Saharan African countries bear the costs of agricultural protection and subsidies, which restricts their market access and depresses the price of export commodities such as cotton.

\footnotetext{
${ }^{33}$ Collier (2006) argues that sub-Saharan Africa's coastal countries should have entered labor-intensive manufacturing in the $1980 \mathrm{~s}$, when East Asia was beginning to transition to this mode of exporting. Entry into the sector now is much more difficult because the agglomeration effects reaped by East Asian countries are difficult to replicate when there are established competitors.

${ }^{34}$ The rules of origin for AGOA, EBA, and the EU Cotonou Agreement - that is, determining how much third-country content is admissible while retaining preferential access - are complex and differ in important ways. Cotonou has quite liberal rules of origin but in other respects is more restrictive than EBA or AGOA; this complexity imposes an additional compliance burden on beneficiary countries.
} 


\section{Box 2. EU-Sub-Saharan Africa Trade Arrangements}

Trade arrangements between the European Union and sub-Saharan Africa are in transition. The Everything But Arms (EBA) initiative allows tariff- and quota-free imports from the world's least developed countries, which includes many though not all countries in subSaharan African. EBA operates within the World Trade Organization (WTO) Generalized System of Preferences (GSP); as a GSP arrangement, it does not require reciprocal trade concessions. The Cotonou Agreement (the successor to the Lomé Convention) grants special tariff preferences to the African, Caribbean, and Pacific (ACP) countries, many of which are former colonies of EU countries. The group of ACP countries is larger than that eligible for EBA preferences only.

New Economic Partnership Agreements are supposed to be in place by the end of 2007. It was ruled that the Cotonou ACP arrangement does not comply with WTO rules because of the preferential nonreciprocal access given to ACP countries beyond those that would have been covered by a GSP arrangement. However, Cotonou was granted a waiver to continue while Economic Partnership Agreements are negotiated between the European Union and regional trade groupings in the ACP. The four African groupings are West Africa (ECOWAS plus Mauritania); Eastern and Southern Africa (a subset of COMESA); Southern Africa (linked to SADC); and Central Africa (CEMAC plus São Tomé and Príncipe and the Democratic Republic of the Congo). South Africa has a separate bilateral EU free trade agreement but is participating in the SADC negotiating group.

Current trade arrangements seem to have had little success in broadening the African export base. The sub-Saharan African share of the EU market for its exports has declined in spite of various trade arrangements and is concentrated in primary commodities. The overlap between agreements has also been problematic. For example, because Cotonou covers more countries, it can offer more favorable rules of origin than EBA-but EBA is more liberal in terms of quota-free access. Rules of origin for both are highly complex and restrict cross-border production. Exclusion of South Africa from both EBA and Cotonou has been difficult to reconcile with its role as an economic hub in the region. Furthermore, special arrangements for certain products, notably sugar and rice, have had a big impact on selected sub-Saharan African countries. ${ }^{1}$

Sub-Saharan African countries appear to have some apprehensions about Economic Partnership Agreements. Because Economic Partnership Agreements must be based on reciprocal concessions to be WTO-compatible, they imply increased market access for EU exporters to African countries. Countries also face customs revenue losses because tariffs on EU imports are reduced. ${ }^{2}$ For instance, customs receipts for the West African Economic and Monetary Union would fall from about 4 percent of GDP to less than 2 percent from the combined effect of the Economic Partnership Agreements and an ECOWAS common external tariff. In fact, the European Union is seeking a gradual phase-in of its reciprocal access to ACP countries to give them time to transition to less distortionary sources of revenue and build up local capacity.

The European Union has emphasized that Economic Partnership Agreements will be part of a regional integration strategy to make African markets more attractive for all producers. One 


\section{Box 2 (concluded)}

goal is an integrated export industry structure; this will include support for dismantling the extensive nontariff barriers and liberalizing investment and trade in services. Economic Partnership Agreements also offer African countries an opportunity to rationalize what is already a complex overlap of regional trading agreements; the average sub-Saharan African country is a member of four such agreements. However, partial implementation of Economic Partnership Agreements without more comprehensive reforms could present risks, because domestic markets would still be distorted, but with more trade diverted to the European Union. ${ }^{3}$ Finally, there is concern that the Economic Partnership Agreement groups are not aligned with sub-Saharan Africa's own regional configuration; the SADC straddles several Economic Partnership Agreements, and there are likely to be continued South African exceptions to the Economic Partnership Agreement process. Countries might also face conflict between participation in an Economic Partnership Agreements and obligations in a regional trade agreement.

The European Union has sought to alleviate concerns about the impact of Economic Partnership Agreements with offers of broad-based market access to participating countries and promises of more effective aid for trade. The most recent proposal (April 2007) envisages EBA-level access for all ACP countries, with phase-ins for only rice and sugar and separate arrangements for a few exports from South Africa. From the perspective of EBA countries, this would erode some preferences but also reduce the obstacles to integration with non-leastdeveloped ACP countries. Nevertheless, rules of origin for inputs sourced outside ACP countries would still be strict, although obtaining more liberal rules of origin is a key point of negotiation for sub-Saharan Africa. AGOA is the prime example of an arrangement under which strict rules of origin are waived. Although African countries have so far expressed little interest in pursuing non-Economic Partnership Agreements, the alternatives for the least developed countries are limited to the EBA; other countries would have access only through the more general GSP provisions. Access under GSP is much less favorable than what an Economic Partnership Agreements would offer, and the rules of origin would be even stricter than now.

${ }^{1}$ Under Cotonou's Sugar Protocol, ACP countries can obtain the (high) internal EU sugar price up to a specified quota, with some additional access above the quota at preferential tariff rates. The European Union's scaling down of its sugar sector supports has imposed significant adjustment on the ACP countries that enjoy this access (such as Mauritius and Swaziland). On the other hand, EBA will offer unrestricted duty-free access to the EU sugar market by 2009. Rice is subject to tariff-rate quota restrictions.

${ }^{2}$ Revenue will also be lower in areas where a customs union is being formed parallel to an Economic Partnership Agreement as in West and Central Africa.

${ }^{3}$ As with RTAs within sub-Saharan Africa, the risk of trade diversion is lessened by parallel mostfavored-nation liberalization. 
Sub-Saharan Africa's own external trade policies do not help. The restrictive external trade regimes of African countries, including high tariffs and other trade barriers, contribute to the undertrading reported in Chapter 3.

Particularly noteworthy are the high tariffs on imported intermediate goods, such as fabric, which place sub-Saharan African firms at a cost disadvantage. ${ }^{35}$ The historic emphasis on import protection shifted relative prices against exporting sectors, discouraging their production. Tariffs on imported intermediate inputs raised the cost of producing exportable goods, and regional trading arrangement incentives to source inputs regionally in compliance with rules of origin placed exportable products at a cost disadvantage on world markets. In a recent working paper, Tokarick (2006) presented export-tax equivalents of tariff barriers in various countries (based on 2001 data). According to the estimates, the tariff structures of Malawi, Mozambique, and Tanzania imposed an effective tax on their exports of about 10 percent.

\section{Policy Recommendations}

Most countries in the region have neither managed to achieve a laborintensive manufacturing export surge, nor been able to climb up the value chain of their commodity-based exports. To improve their prospects for doing either, the following policies should be helpful.

Maintaining macroeconomic stability, building infrastructure, and reducing the cost of doing business are universally essential to promoting growth and trade. They would also help the region gain a share of the growing outsourcing of services by industrial countries (see Box 3).

Sub-Saharan African countries should proceed with trade liberalization through a gradual but substantial reduction in MFN tariffs around the region and in the external tariffs in regional trading agreements. ${ }^{36}$ This will improve resource allocation while limiting incentives to circumvent customs. It will also reduce the risk of trade diversion in regional trading agreements and the EU Economic Partnership Agreements. Of course sub-Saharan Africa would also benefit from global trade liberalization, especially improved access to Asian markets, where it currently lacks the preferential access it has to the European Union and the United States. In general, MFN tariff reductions are a much more powerful instrument than RTAs for achieving gains from trade, because all trade, not just trade within the RTA, is affected.

\footnotetext{
${ }^{35}$ An extreme example in this regard is Nigeria, which bans imported fabric.

${ }^{36}$ The average effective tariff in sub-Saharan Africa is still the highest among developing regions, though it has fallen from 22 percent in 1997 to 15 percent in 2006. The average masks large variation among countries and commodities.
} 


\section{Box 3. International Service Outsourcing to Sub-Saharan Africa}

International service outsourcing (ISO) refers to companies procuring services in foreign countries (Amiti and Wei, 2004). It is estimated that ISO generates $\$ 160$ million- $\$ 200$ billion a year, and its annual growth rate exceeds 20 percent (Bartels, 2005). ISO ranges from relatively low-value-added data coding and customer service (call centers) to more sophisticated business processing (billing services, claims processing) to high-value-added information technology and professional services (accounting, health care, engineering).

ISO to sub-Saharan Africa has so far been marginal. It is concentrated in just a few countries and in low-value-added activities. Call centers in Ghana, Kenya, and Senegal employ several thousand people (Day, 2005; and Lacey, 2005). South Africa as the regional leader has more than 30,000 call center jobs, but that is still only 0.5 percent of call center jobs worldwide (Lacey, 2005).

Sub-Saharan Africa has considerable disadvantages in building the ISO sector but it has some advantages over better-known ISO locations. The challenges it must confront are formidable: high telecommunication costs, unreliable supplies of electricity, poor transport infrastructure, lack of skilled workers, and relatively high wages (Zachary, 2004). Yet countries in sub-Saharan Africa benefit from dedicated employees who prize their jobs, falling phone rates due to a new fiber-optic connection to Europe, and European time zones. South Africa in particular can draw on a reservoir of business skills from its mature insurance and banking sectors (McLaughlin, 2004; and Farrell, 2006).

The key to attracting ISO to sub-Saharan Africa is public investment in infrastructure and education. Good infrastructure reduces setup and operating costs for most businesses and is of particular importance for ISO, an industry that depends heavily on reliable communication links. Local employees who possess the necessary skills are also crucial. Because countries in sub-Saharan Africa often lag behind countries elsewhere in providing infrastructure and education, public investment in these areas would benefit not only the outsourcing industry but also the economy as a whole.

Hallaert (2007) finds, for example, that Madagascar would benefit more from phaseout of customs tariffs for the SADC trade if it were accompanied by MFN tariff reduction; SADC accounts for just 6 percent of Malagasy imports, but there is substantial potential for trade diversion with an SADConly liberalization.

RTAs should seek to broaden their product coverage to all goods and services. They should also promote liberal rules of origin; requirements for high domestic or regional value added are difficult for sub-Saharan African exporters to meet. The Economic Partnership Agreements now being negotiated with the European Union may be a way to address nontariff barriers in RTAs. Policy reforms that help draw more firms into the formal sector are essential for boosting exports, because the logistical requirements 
of exporting are difficult, if not impossible, for an informal sector firm to meet (Krueger, 2007).

Reducing shipping costs is an important objective for sub-Saharan Africa. Although direct global shipping costs have declined over time and are the least constraining element on sub-Saharan Africa's trade linkages, there are indirect costs related to infrastructure quality and institutions, such as port charges, customs clearing, and internal freight. These, which often far exceed international freight costs, are a major source of relative cost differentials between countries (Martin, 2005). Moreover, a global reduction in shipping costs does not necessarily translate into an equivalent reduction for subSaharan Africa because the East Asian trade boom has reoriented fleets toward the Pacific Ocean. One study (Hummels, 2001) estimates that each extra day of shipping time adds 0.8 percent to ad valorem costs - an important consideration when picking up cargo in a sub-Saharan African port requires a detour from a regular shipping route. Delays before shipping also have an adverse impact. Djankov, Freund, and Pham (2006) use the World Bank's Doing Business data to estimate that each additional day's delay before shipping reduces trade by 1 percent. Delays are particularly costly for time-sensitive perishable goods of the type that sub-Saharan Africa is likely to be exporting.

Coastal countries should work to boost their attractiveness to global intraindustry trade networks. That means tackling the domestic portion of indirect costs like transportation and logistics, especially such bottleneck areas as customs clearance. Trade liberalization can help attract multinational firms whose operations are spread throughout the world. Liberalizing their trade with neighboring landlocked countries can help coastal countries become regional hubs for distribution or assembly. RTAs help, but the emphasis should be on deepening agreements through progress on nontariff barriers rather than adding new RTAs. ${ }^{37}$ Because international trade networks are increasingly involved in services as well as goods, improvements in telecommunications are also critical.

Landlocked countries should emphasize reduction in transportation costs and deeper regional integration, in particular with coastal countries. This would facilitate adding value to their traditional exports and allow them to better exploit their preferential access to the European Union and the United States. Improved regional infrastructure will also expand market size, but it will be effective only if border and other checkpoint procedures are rationalized. A special emphasis on streamlined trade logistics would greatly benefit landlocked countries. Although it may not be currently feasible for

\footnotetext{
${ }^{37}$ Hinkle and Newfarmer (2006) note that the negotiation of EPAs with the European Union will require
} clarification of conflicting obligations under overlapping RTAs of which a country may be a member. 
these countries to build major manufacturing capacity, they could expand domestic processing of agricultural and raw materials in line with the experience of higher-income countries that continue to specialize in agriculture. For example, tea and coffee have declined to minor shares of sub-Saharan African exports, even though they are sold as premium products in industrialized countries. The export of low-value primary products is particularly ineffective for sub-Saharan Africa when total transport costs are so high, creating a large wedge between the final sales price and the primary producer. Beverage exporters could capture more value by packaging, branding, and grading these exports, but they will need assistance from partners to build up their capacity in those areas. Promotion of manufacturing should be based on existing advantages and should focus on enhancing local capacity rather than interventions like subsidies or export taxes. For example, domestic production of cotton yarn would lessen the burden of rules of origin in preferential trade agreements and mitigate uncertainty about the future renewal of AGOA, with its more liberal rules of origin. However, efforts to expand yarn production within the public sector have not been successful, and the record of export taxes on raw cotton shows that they penalize cotton growers.

Resource-intensive countries should tackle constraints on their export processing industries. However, many of sub-Saharan Africa's resource exporters have small populations, which limits their ability to diversify their economies, and Dutch disease effects make it more difficult for industrial sectors of their economies to be internationally competitive. However, these countries often lack the capacity to add more value to their resource endowments. Diamonds are shipped from southern Africa to Europe (and, increasingly, India) for grading and polishing. Oil is exported in crude form for refining in a third country and then re-imported for retail sale. Metals and ores leave the region immediately after extraction for use in manufacturing processes in other parts of the world. Experiences outside sub-Saharan Africa show that it is possible to remain relatively specialized in resourcebased exporting at higher income levels, but this is contingent on moving up the value chain. However, attempts to encourage local processing through export taxes or controls on raw commodities have not been successful: some of the burden is borne by domestic suppliers, and the implicit subsidy to the processing stage gets dissipated in rents. In fact, constraints may not be industry-specific and may instead relate to a generally restrictive business environment. Because developing downstream industries is often capitalintensive, openness to foreign investment is particularly important; this is one area the Economic Partnership Agreement process is designed to tackle.

Sub-Saharan African countries will need assistance in boosting their capacity to compete in global export markets. Many of the hurdles to exporting derive from technical and quality standards needed for entry to certain markets; this is especially so for attempts to move up the value chain in processing of 
primary products. Sub-Saharan African countries would benefit from cooperation with partners in industrialized countries in building this capacity. The scope for seeking out partnerships with Asian firms is significant as their home labor costs rise and given their successful experience in entering western markets; nevertheless, sub-Saharan Africa will be an attractive base for these firms only if the general environment for doing business improves. In addition, the new Economic Partnership Agreements with the European Union open the way for enhanced capacity-building strategies such as aid for trade. Regional harmonization of standards would also help reduce trading costs and expand the effective size of the market available to otherwise segmented sub-Saharan African firms. 


\section{Data Source and Notes}

The analysis uses UN Comtrade data on sub-Saharan African merchandise (physical goods) exports, as reflected in imports to the reporting country under Standard International Trade Classification (SITC) revision 2. This is a more reliable method of measuring sub-Saharan African exports, given data quality problems when the sub-Saharan African country is the reporting country. The reporting countries/groups are the United States; the pre-2004 European Union, referred to as EU-15; Hong Kong SAR, Japan, Republic of Korea, and Singapore (collectively referred to as Industrial Asia); and China, India, Indonesia, Malaysia, Taiwan Province of China, and Thailand (collectively referred to as Developing Asia). Although these groups do not include all of sub-Saharan Africa's trade partners, they capture the main reporting partners for sub-Saharan Africa in Comtrade. Two years are chosen for detailed comparison: usually 1985 and 2005, though data gaps sometimes necessitated the use of 1990 or 2004. The data cover merchandise (including manufacturing) exports from sub-Saharan Africa to each of the countries or groupings and are expressed in nominal U.S. dollars.

For the sub-Saharan African countries, the analytical subgroups are resourceintensive (oil and non-oil), coastal, and landlocked countries. The listing is provided in Table A2 and is identical to that used in the IMF's Regional Economic Outlooks for sub-Saharan Africa. Collier (2006) explains why the division is analytically useful. Collier and O'Connell (2006) explain the classification of countries into each group. For reasons explained below, the non-oil resource-intensive classification is of limited usefulness with Comtrade data.

In Chapters 2 and 3, the definition of sub-Saharan Africa corresponds to that of the World Bank and therefore includes Djibouti, Mauritania, and Sudan. These countries, which are not covered by the IMF's African Department, are not included in the subgroups used in Chapter 4. To maintain consistency of aggregation among the subgroups and the total for all countries, this chapter therefore excludes the three countries from the sub-Saharan African aggregate calculation. 
Although comprehensive in many respects, the Comtrade data have some important limitations. One of the most important for the analysis of subSaharan African subgroups is that Southern African Customs Union countries other than South Africa have been reporting separate data to Comtrade only since 2000. Two of these countries (Botswana and Namibia) are important non-oil resource-intensive countries whose high-value exports have a large influence on the group. This impedes the ability to analyze trends by comparing years before and after 2000; such comparisons are therefore not reported for the non-oil resource-intensive group. Although Lesotho and Swaziland are also affected by this exclusion, they have a less dominant impact on the landlocked group.

Comtrade data also have some reporting gaps. China does not report data for many product categories for 1985, and no Indian data are yet available for 2005. Furthermore, India does not report fuel imports to Comtrade.

Although the values involved of these limitations are relatively small, they should be borne in mind when interpreting the tables and charts.

The four broad sectoral classifications are formed from single-digit SITC categories: food and beverages (SITCs 0, 1, and 4), raw materials (SITC 2), fuels (SITC 3), and manufactures and chemicals (SITCs 5-8). 


\section{Additional Tables and Figures}

Table A1. Export Shares of Major Product Categories, 1995 and 2005 (In percent, ranked by 2005 shares)

\begin{tabular}{lcccc}
\hline & & \multicolumn{3}{c}{ Share of Nonfuel Exports } \\
\cline { 3 - 5 } Three-Digit Category & Product Code & 1985 & 1995 & 2005 \\
\hline Manufacturing & & & & \\
Pearls and precious stones & 667 & 3.9 & 10.6 & 14.1 \\
Silver and platinum & 681 & 4.8 & 4.9 & 8.4 \\
Iron blocks & 671 & 3.6 & 4.0 & 4.7 \\
Aluminum & 684 & 0.8 & 1.6 & 4.1 \\
Clothing & 841 & 1.3 & 4.0 & 3.8 \\
Road motor vehicles & 732 & 0.2 & 0.8 & 3.6 \\
Nonelectrical machinery & 719 & 0.1 & 0.8 & 2.5 \\
Copper & 682 & 7.7 & 3.6 & 1.6 \\
Iron sheets & 674 & 0.8 & 0.6 & 1.4 \\
Ships & 735 & 1.7 & 0.4 & 1.3 \\
Wood boards & 631 & 0.7 & 1.1 & 1.3 \\
Inorganic chemical elements & 522 & 0.8 & 0.6 & 1.1 \\
Iron (preshaped) & 672 & 0.4 & 0.9 & 1.0 \\
Share of above in total exports & & 26.7 & 33.7 & 48.9 \\
Share of all manufacturing & & 37.1 & 44.4 & 59.0 \\
Nonmanufacturing & & & & \\
Cocoa & 072 & 9.9 & 6.3 & 5.6 \\
Fruit and nuts & 057 & 3.1 & 4.5 & 4.5 \\
Base metal ores and concentrates & 287 & 5.0 & 3.2 & 3.8 \\
Iron ore and concentrates & 281 & 4.1 & 2.1 & 2.9 \\
Cotton & 263 & 2.7 & 3.2 & 1.9 \\
Fish & 034 & 0.7 & 1.9 & 1.9 \\
Wood (rough) & 247 & 2.8 & 3.6 & 1.7 \\
Wood (simple forms) & 248 & 0.9 & 2.2 & 1.5 \\
Shellfish & 036 & 1.5 & 2.4 & 1.5 \\
Sugar and honey & 061 & 2.6 & 2.4 & 1.5 \\
Coffee & 071 & 0.9 & 1.7 & 1.4 \\
Raw vegetable materials & 292 & & 1.3 & 1.3 \\
& & & & \\
& & & & \\
\end{tabular}


Table A1 (concluded)

\begin{tabular}{lcccc}
\hline & & \multicolumn{3}{c}{ Share of Nonfuel Exports } \\
\cline { 3 - 5 } Three-Digit Category & Product Code & 1985 & 1995 & 2005 \\
\hline & 121 & 1.7 & 1.7 & 0.9 \\
Tobacco & 074 & 1.7 & 0.7 & 0.3 \\
Tea & 268 & 1.5 & 0.4 & 0.2 \\
Wool & & & & \\
$\quad \begin{array}{l}\text { Share of above in total } \\
\quad \text { (percent) }\end{array}$ & 51.8 & 43.2 & 31.4 \\
\hline
\end{tabular}

Source: UN Comtrade.

Note: The indicated categories are at the three-digit SITC level and are those that accounted for at least 1 percent of total sub-Saharan African nonfuel exports in 1985.

Table A2. Subgroups of Countries

\begin{tabular}{|c|c|c|c|}
\hline Oil-Producing & Coastal & Landlocked & $\begin{array}{l}\text { Non-Oil } \\
\text { Resource-Intensive }\end{array}$ \\
\hline Angola & Benin & Burkina Faso & Botswana \\
\hline Cameroon & Cape Verde & Burundi & Guinea \\
\hline Congo, Rep. of & Comoros & Central African Rep. & Namibia \\
\hline Equatorial Guinea & Côte d'Ivoire & Chad & São Tomé and Príncipe \\
\hline Gabon & The Gambia & Congo, Dem. Rep. of & Sierra Leone \\
\hline \multirow[t]{11}{*}{ Nigeria } & Ghana & Ethiopia & Zambia \\
\hline & Guinea-Bissau & Lesotho & \\
\hline & Kenya & Malawi & \\
\hline & Madagascar & Mali & \\
\hline & Mauritius & Niger & \\
\hline & Mozambique & Rwanda & \\
\hline & Senegal & Swaziland & \\
\hline & Seychelles & Uganda & \\
\hline & South Africa & Zimbabwe & \\
\hline & Tanzania & & \\
\hline & Togo & & \\
\hline
\end{tabular}

Source: Collier and O'Connell (2007).

Note: See Appendix 1. 
Figure Ala. Selected Economies: Food and Beverage

(Percent of total exports)

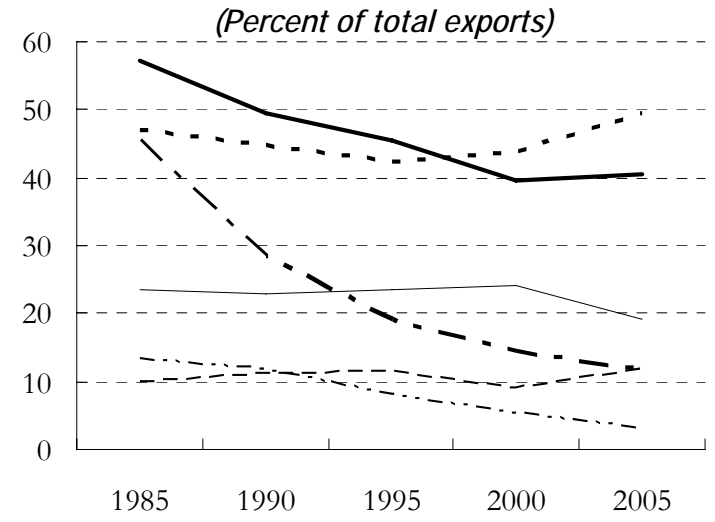

Figure Alc. Selected Economies: Manufacturing Share of Total Exports (Percent of total exports)

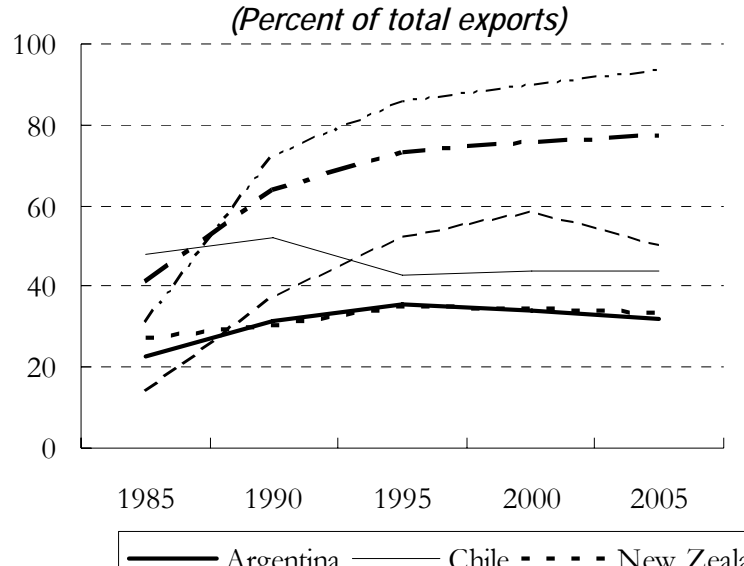

Argentina Chile - - - - New Zealand
Figure Alb. Selected Economies: Crude Inedible Materials

(Percent of total exports)

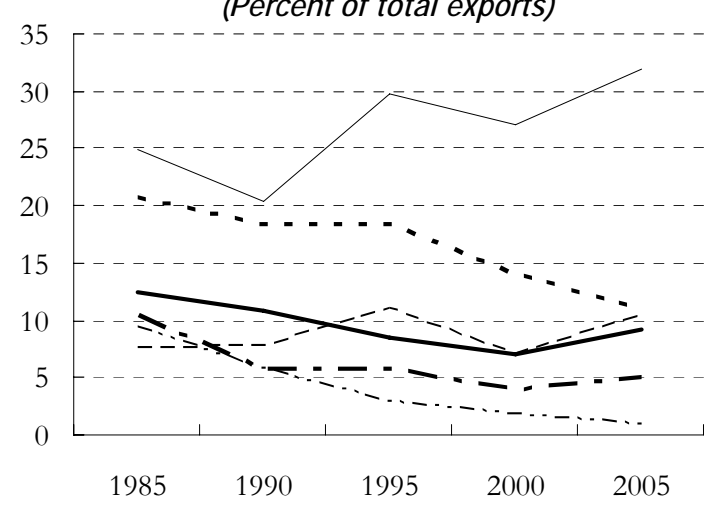

Figure Ald. Selected Economies: Fuels

Share of Total Exports

(Percent of total exports)

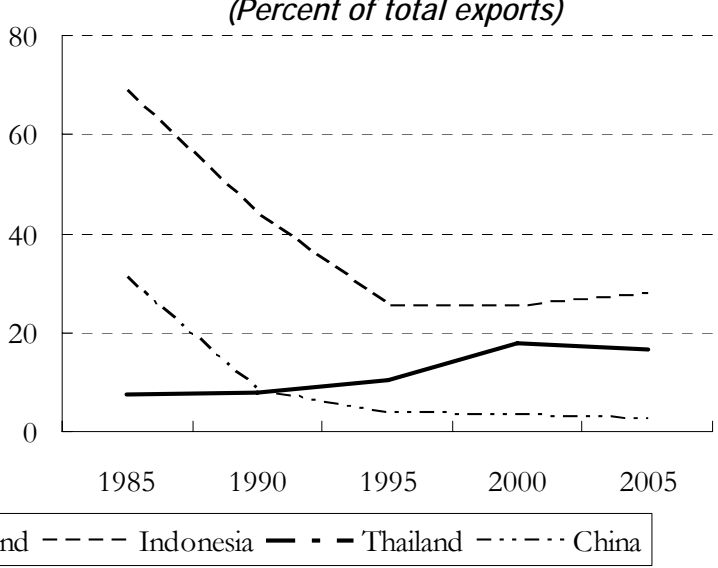

Source: UN Comtrade.

Note: Three countries are omitted from panel (d) because their fuel export shares are always tiny. 


\section{References}

Amiti, Mary, and Shang-Jin Wei, 2004, "Fear of Service Outsourcing: Is It Justified?” IMF Working Paper 04/186 (Washington: International Monetary Fund).

Baldwin, Richard, and Daria Taglioni, 2006, "Gravity for Dummies and Dummies for Gravity Equations,” NBER Working Paper No. 12516 (Cambridge, Massachusetts: National Bureau of Economic Research).

Bartels, F.L., 2005, “Outsourcing Markets in Services: International Business Trends, Patterns, and Emerging Issues,” Working Paper IWPS 002/05 (Vienna: United Nations Industrial Development Organization). Available via the Internet: www.unido.org/ $\mathrm{doc} / 38082$.

Bigsten, Arne, and Måns Söderbom, 2006, “What Have We Learned from a Decade of Manufacturing Enterprise Surveys in Africa?" World Bank Research Observer, Vol. 21, No. 2 (Fall), pp. 241-65.

Broadman, Harry G., 2007, Africa's Silk Road: China and India's New Economic Frontier (Washington: World Bank).

Centre for Chinese Studies, 2006, China's Interest and Activity in Africa's Construction and Infrastructure Sectors, study commissioned by the U.K. Department for International Development (Stellenbosch, South Africa: Stellenbosch University).

Coe, David T., and Alexander W. Hoffmaister, 1999, "North-South Trade: Is Africa Unusual?" Journal of African Economies, Vol. 8, No. 2 (July), pp. 228-56.

Collier, Paul, 2006, “Africa: Geography and Growth," paper presented at the Federal Reserve Bank of Kansas City Symposium on The New Economic Geography, Jackson Hole, Wyoming, August 24-26. Available via the Internet: www.kansascityfed.org/PUBLICAT/ SYMPOS/2006/pdf/17Collier.pdf.

_ and Stephen O'Connell, 2007, “Opportunities and Choices," Chapter 2 in The Political Economy of Economic Growth in Africa, 1960-2000, ed. by Benno J. Nduluu, Stephen A. O’Connell, Robert H. Bates, Paul Collier, and Charles C. Soludo (Cambridge: Cambridge University Press, forthcoming). 
Day, P., 2005, “Talk Is Profitable in Ghana,” BBC News broadcast, April 23. Available via the Internet: news.bbc.co.uk/2/hi/programmes/ from_our_own_correspondent/4473073.stm.

Djankov, Simeon, Caroline Freund, and Cong S. Pham, 2006, "Trading on Time," Policy Research Working Paper No. 3909 (Washington: World Bank).

Dudine, Paolo, James John, Mark Lewis, Luzmaria Monasi, Helaway Tadesse, and Joerg Zeuner, 2006, "Weathering the Storm So Far: The Impact of the 2003-05 Oil Shock on Low-Income Countries," IMF Working Paper 06/171 (Washington: International Monetary Fund).

Eifert, Benn, Alan Gelb, and Vijaya Ramachandran, 2005, "Business Environment and Comparative Advantage in Africa: Evidence from the Investment Climate Data," Working Paper No. 56 (Washington: Center for Global Development).

Energy Information Administration (EIA), 2006, International Energy Annual 2004 (Washington: United States Department of Energy).

Farrell, Diana, 2006, "Smarter Offshoring," Harvard Business Review, Vol. 84, No. 6 (June), pp. 84-92.

Gallup, John, Jeffrey Sachs, and Andrew Mellinger, 1998, "Geography and Economic Growth," paper presented at the World Bank Annual Bank Conference on Development Economics, Washington, April 20-21.

Goldstein, Andrea, Nicolas Pinaud, Helmut Reisen, and Xiaobao Chen, 2006, The Rise of China and India: What's in It for Africa? (Paris: Organization for Economic Cooperation and Development).

Gupta, Sanjeev, and Yongzheng Yang, 2006, “Unblocking Trade,” Finance and Development, Vol. 43, No. 4 (December), pp. 22-25.

Hallaert, Jean-Jacques, 2007, "Can Regional Integration Accelerate Development in Africa? CGE Model Simulations of the Impact of the SADC FTA on the Republic of Madagascar," IMF Working Paper 07/66 (Washington: International Monetary Fund).

Heston, Alan, Robert Summers, Daniel A. Nuxoll, and Bettina Aten, 1995, Penn World Tables Version 5.6, Center for International Comparisons at the University of Pennsylvania (Philadelphia: University of Pennsylvania).

Hinkle, Lawrence E., and Richard S. Newfarmer, 2006, "Risks and Rewards of Regional Trading Arrangements in Africa: Economic Partnership Agreements between the European Union and Sub-Saharan Africa," in Annual World Bank Conference on Development Economics 2006: Growth and Integration (Senegal Proceedings), ed. by François Bourguignon and 
Boris Pleskovic (Washington: International Bank for Reconstruction and Development and World Bank).

Hummels, David, 2001, “Time as a Trade Barrier” (unpublished; West

Lafayette, Indiana: Department of Economics, Purdue University).

Available via the Internet: www.mgmt.purdue.edu/faculty/

hummelsd/research/time3b.pdf.

International Monetary Fund, 2002, World Economic Outlook (Washington: September).

__, 2006a, Regional Economic Outlook: Sub-Saharan Africa (Washington: May).

_- 2006b, Regional Economic Outlook: Sub-Saharan Africa (Washington: September).

—_, 2007, Regional Economic Outlook: Sub-Saharan Africa (Washington: April).

Johnson, Simon, Jonathan D. Ostry, and Arvind Subramanian, 2007, “The Prospects for Sustained Growth in Africa: Benchmarking the Constraints," IMF Working Paper 07/52 (Washington: International Monetary Fund).

Jones, Ronald W., 2000, Globalization and the Theory of Input Trade (Cambridge, Massachusetts: MIT Press).

Krueger, Anne O., 2007, "Understanding Context and Interlinkages in Development Policy Formulation and Implementation," paper presented at the American Economics Association Annual Meetings, Chicago, January 5-7.

Lacey, M., 2005, “Accents of Africa: A New Outsourcing Frontier,” New York Times, February 2.

Limão, Nuno, and Anthony J. Venables, 2001, "Infrastructure, Geographical Disadvantage, Transport Costs, and Trade," World Bank Economic Review, Vol. 15, No. 3, pp. 451-79.

Linders, Gert-Jan M., and Henri L.F. de Groot, 2006, "Estimation of the Gravity Equation in the Presence of Zero Flows," Discussion Paper No. 06-072/3 (Amsterdam: Tinbergen Institute).

Martin, Will, 2005, “Outgrowing Resource Dependence: Theory and Some Recent Developments,” Policy Research Working Paper No. 3482 (Washington: World Bank).

Mattoo, Aaditya, Devesh Roy, and Arvind Subramanian, 2003, “The Africa Growth and Opportunity Act and Its Rules of Origin: Generosity Undermined?" World Economy, Vol. 26, No. 6 (June), pp. 829-51. 
McLaughlin, A., 2004, “Where America's White-Collar Jobs Go: It's Not Just India," Christian Science Monitor, February 26.

McLeary, Paul, 2007, “A Different Kind of Great Game,” Foreign Policy (March). Available via the Internet: www.foreignpolicy.com/story/ cms.php?story_id=3744.

Mengistae, Taye, and Catherine Pattillo, 2004, "Export Orientation and Productivity in Sub-Saharan Africa," IMF Staff Papers, Vol. 51, No. 2 (August), pp. 327-53.

Moreira, Mauricio Mesquita, 2007, "Fear of China: Is There a Future for Manufacturing in Latin America?" World Development, Vol. 35 (March), pp. 355-76.

Ramachandran, Vijaya, and M.K. Shah, 1999, "Minority Entrepreneurs and Firm Performance in Sub-Saharan Africa," Journal of Development Studies, Vol. 36, No. 2 (December), pp. 71-87.

Rodrik, Dani, 1994, "Getting Interventions Right: How South Korea and Taiwan Grew Rich,” NBER Working Paper No. 4964 (Cambridge, Massachusetts: National Bureau of Economic Research).

Rose, Andrew K., 2002, "Estimating Protectionism Through Residuals from the Gravity Model" (unpublished; Berkeley, California: University of California Haas School of Business). Available via the Internet: www.faculty.haas.berkeley.edu/arose/WEO.pdf.

_ 2004, "Do We Really Know That the WTO Increases Trade?" American Economic Review, Vol. 94, No. 1 (March), pp. 98-114.

Tokarick, Stephen, 2006, "Does Import Protection Discourage Exports?" IMF Working Paper 06/20 (Washington: International Monetary Fund).

Tsangarides, Charalambos G., Pierre Ewenczyk, and Michal Hulej, 2006, "Stylized Facts on Bilateral Trade and Currency Unions: Implications for Africa,” IMF Working Paper 06/31 (Washington: International Monetary Fund).

UNAIDS/UNICEF/USAID, 2004, Children on the Brink 2004: A Joint Report of New Orphan Estimates and a Framework for Action (New York and Washington).

UNAIDS/WHO, 2006a, AIDS Epidemic Update-December 2006 (Geneva). , 2006b, 2006 Report on the Global AIDS Epidemic (Geneva).

Winters, L. Alan, and Shahid Yusuf, 2007, Dancing With Giants: China, India, and the Global Economy (Washington: International Bank for Reconstruction and Development, World Bank, and Institute of Policy Studies). 
World Bank, 2004, Patterns of Africa-Asia Trade and Investment: Potential for Ownership and Partnership, Africa Region, Private Sector Unit Working Paper Report No. 33666 (Washington: World Bank).

Yang, Yongzheng, and Sanjeev Gupta, 2005, "Regional Trade Arrangements in Africa: Past Performance and the Way Forward," IMF Working Paper 05/36 (Washington: International Monetary Fund).

Zachary, G.P., 2004, “Outsourcing in Africa,” Project Syndicate (June). Available via the Internet: www.project-syndicate.org/commentary/ zachary2. 